
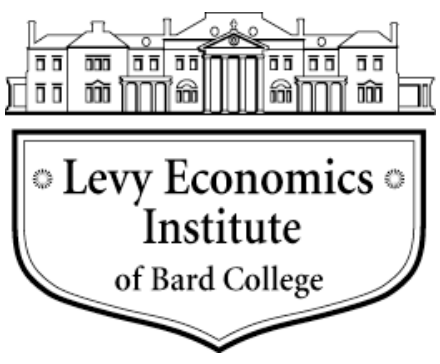

Working Paper No. 831

\title{
Beyond Market Failures: The Market Creating and Shaping Roles of State Investment Banks
}

by

\author{
Mariana Mazzucato ${ }^{\dagger}$ \\ University of Sussex
}

Caetano C.R. Penna

University of Sussex

January 2015

\begin{abstract}
* The authors would like to thank Professor Rainer Kattel, Professor Lavinia Barros de Castro, and two anonymous reviewers (from the Science Policy Research Unit [SPRU] Working Paper Series) for invaluable comments (the usual disclaimers apply).

$\dagger$ m.mazzucato@sussex.ac.uk

†c.penna@sussex.ac.uk

This paper was prepared for the project "Financing Innovation: An Application of a Keynes-SchumpeterMinsky Synthesis," funded in part by the Institute for New Economic Thinking, INET grant no. IN012-00036, administered through the Levy Economics Institute of Bard College; Mariana Mazzucato (Science Policy Research Unit, University of Sussex) and L. Randall Wray (Levy Institute) are the project's co-principal investigators. The authors thank INET, the Levy Institute, and the Ford Foundation for support of this research.
\end{abstract}

The Levy Economics Institute Working Paper Collection presents research in progress by Levy Institute scholars and conference participants. The purpose of the series is to disseminate ideas to and elicit comments from academics and professionals.

Levy Economics Institute of Bard College, founded in 1986, is a nonprofit, nonpartisan, independently funded research organization devoted to public service. Through scholarship and economic research it generates viable, effective public policy responses to important economic problems that profoundly affect the quality of life in the United States and abroad.

Levy Economics Institute

P.O. Box 5000

Annandale-on-Hudson, NY 12504-5000

http://www.levyinstitute.org

Copyright (C) Levy Economics Institute 2015 All rights reserved 


\begin{abstract}
Recent decades witnessed a trend whereby private markets retreated from financing the real economy, while, simultaneously, the real economy itself became increasingly financialized. This trend resulted in public finance becoming more important for investments in capital development, technical change, and innovation. Within this context, this paper focuses on the roles played by a particular source of public finance: state investment banks (SIBs). It develops a conceptual typology of the different roles that SIBs play in the economy, which together show the market creation/shaping process of SIBs rather than their mere "market fixing" roles. This paper discusses four types of investments, both theoretically and empirically: countercyclical, developmental, venture capitalist, and challenge led. To develop the typology, we first discuss how standard market failure theory justifies the roles of SIBs, the diagnostics and evaluation toolbox associated with it, and resulting criticisms centered on notions of "government failures." We then show the limitations of this approach based on insights from Keynes, Schumpeter, Minsky, and Polanyi, as well as other authors from the evolutionary economics tradition, which help us move toward a framework for public investments that is more about market creating/shaping than market fixing. As frameworks lead to evaluation tools, we use this new lens to discuss the increasingly targeted investments that SIBs are making, and to shed new light on the usual criticisms that are made about such directed activity (e.g., crowding out and picking winners). The paper ends with a proposal of directions for future research.
\end{abstract}

Keywords: Development Banking; Market Failure; Mission-oriented Finance; Public Finance; State Investment Banks

JEL Classifications: G20, L52, O16, O38, P16 


\section{INTRODUCTION: STATE INVESTMENT BANKS AS SOURCES OF MISSION- ORIENTED FUNDING FOR INNOVATION}

Recent years have witnessed state investment banks increasing their role in areas where the private sector fears to tread. This includes, for example, the emerging "green" economy: worldwide investments aimed at the global challenges of limiting carbon emissions. Figure 1 shows that in 2012, the share of development finance institutions (in this case, state investment banks, or SIBs) in the "climate finance landscape" was 34 percent (the highest share of any single type of actor), compared to 29 percent for project developers (including state-owned utilities), 19 percent for corporate actors, 9 percent for households, 6 percent for all types of private financial institutions, and 3 percent for executive governments (investments from governmental budgets) (Climate Policy Initiative, 2013).

Figure 1 Finance for Climate Change Adaptation and Mitigation Projects by Source in 2012

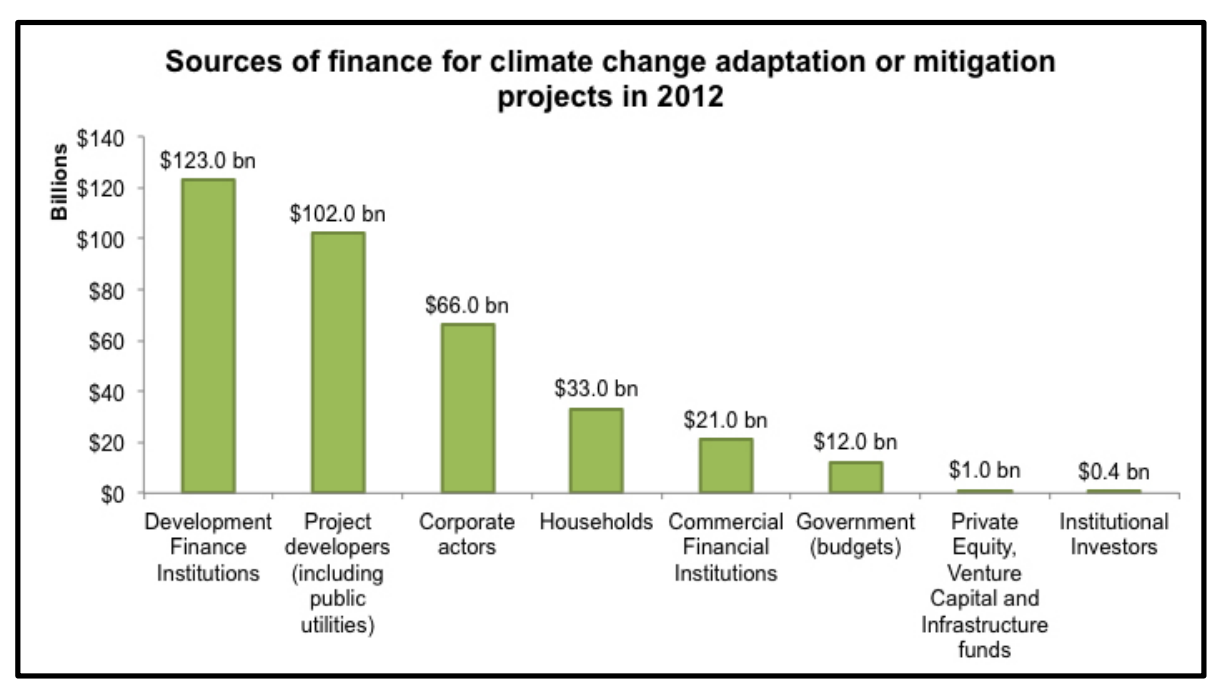

Source: Based on data from Climate Policy Initiative (2013).

This level of investment directed toward an emerging new area recalls the role that state agencies played in the internet and biotech revolutions. In such cases, public investments did not only "fix failures in markets," but they actively created them by investing across the entire innovation chain, from basic research to early stage commercialization (Mazzucato, 2013a) under the guidance of overarching technological missions. The literature on mission-oriented policy has under-conceptualized, however, the importance of the type of funding sources and financial instruments for mission-oriented policies. This strand of research has focused on demand-side innovation policies, such as the role that military procurement has played in 
technical change and radical innovation (Fuchs, 2010; Mowery, 2010, 2012; see also Edquist and Zabala-Iturriagagoitia, 2012). More recently, a special issue of the journal Research Policy (Volume 41, Issue 10) has featured studies that looked at a limited number of financial (supplyside) tools; namely, non-reimbursable public finance for basic research and innovation, such as grants (Sampat, 2012; Wright, 2012), subsidies (including tax credits; see Veugelers, 2012), and innovation prizes (Murray et al., 2012). While the role of public R\&D agencies in this process has been studied at length (Mowery, 2010; Foray et al. 2012), the role of public banks in shaping such markets has not been studied.

It is important to study alternative sources of mission-oriented funding for innovation due to the differences between missions of the past and contemporary missions - the grand societal challenges that increasingly provide a rationale for economic growth and science, and technology and innovation strategies, as in the case of the European Commission's new framework for research and innovation funding (EC, 2011). The historical missions (best exemplified by the Apollo and Manhattan programs) were clearly related to outcomes, such as putting a man on the moon or developing the atom bomb. Modern missions such as addressing the ageing/demographic problem or climate change are more complex, as there is less of a clear technological objective signalling when the mission is accomplished (Soete and Arundel, 1993; Foray et al., 2012). Contemporary missions aim to address broader and persistent challenges that require long-term commitments to the development of many technological solutions and "a continuing high rate of technical change and a set of institutional changes" (Freeman, 1996, p. 34).

Soete and Arundel (1993, p. 51) provide a characterization of old and new missions, on which we draw to highlight the importance of the type of funding sources for the development of mission-oriented innovation, and why we believe state investment banks are well positioned to fund these new missions (as they are already doing in the case of climate change). Because old missions were defined through a top-down, centralized process, funding sources were executive agencies that were insulated from the rest of society and defined the scope of the mission-oriented policies, and selected a restricted number of firms to develop radical technologies. As these old missions sought to develop radical technologies, regardless of their economic feasibility, grants and subsidies (non-reimbursable funding) or public procurement (which guaranteed demand for technologies) were used successfully. In the case of new missions (environmental and others), this centralized model that has executive agencies as its 
funding source will not work for several reasons. First, economic feasibility will be as important as technological feasibility, because the new technologies will have to compete with incumbent ones. Second, the new missions target technologies for areas in which many stakeholders participate, such as energy systems, health systems or society at large (as in the case of climate change). Third, in new missions, mass diffusion throughout the economy is crucial and needs to take place together with technology development. Fourth, incremental innovation is as important as radical innovation, as in the case of energy efficiency measures that help cut carbon emissions. And finally, mission-oriented policies (such as finance for low-carbon innovation) must be coordinated with other policies that affect the targeted domain (for example, carbon emission standards and targets).

In light of these characteristics, central funding sources (executive agencies), as for the historical missions, seem ill-positioned to promote mission-oriented investments. This creates the need for alternative sources, and SIBs are appropriate in this regard. Because these are banking institutions, they already have the capability and knowledge to access the economic feasibility of projects. Moreover, SIBs have traditionally supplied long-term funding (for capital-intensive projects, for example), and patient long-term committed capital is crucial for making new mission-oriented projects economically feasible. Banking institutions are also well positioned to coordinate stakeholders, as part of the development banking process is to coordinate stakeholders, to establish relationships, and to build up a network with an array of actors (from government officials to corporate actors to consumers). The fact that SIBs have a vast portfolio of funding tools (equity, loans, grants, etc.) will likely enable them to match the most appropriate tool to the project, whether it is incremental or radical (for example, equity or risk contracts for radical innovation, loans to incremental innovation projects, and grants to blue sky R\&D). Finally, SIBs have traditionally executed their roles in coordination with governmental policies (industrial strategy plans), and new missions could potentially build on this important node in the governmental network.

Given the actual and potential contribution of SIBs in terms of mission-oriented funding for innovation, the goal of this paper is to improve our understanding of the different roles that such public banks play, both historically (over time) and across the production landscape. While SIBs are not new, they diversified their roles in the past three decades, going beyond traditional activities in both scale and scope. In so doing, they have promoted the following four types of investments: (1) countercyclical finance to offset the credit crunch during economic recessions 
(Gutierrez et al., 2011; Luna-Martinez and Vicente, 2012); (2) funding for long-term projects, industrialization and capital development of the economy (Griffith-Jones and Tyson, 2013); (3) targeted investments in high-risk R\&D, innovative start-ups, and lengthy innovations-areas in which private capital has proved to be too short-termist and risk averse to venture into (George and Prabhu, 2003; Schapiro, 2012; Hochstetler and Montero, 2013; Sanderson and Forsythe, 2013); and (4) promotion of investments around complex societal problems, such as climate change and the ageing crisis (Schröder et al., 2011). This paper proposes a new typology through which to understand the market shaping and creating roles of state investment banks; a framework that goes beyond the usual emphasis on the "market-failure fixing" role of public sector activity.

The standard market failure framework used by economists to inform the formulation and evaluation of public investments is problematic because it explains public intervention in the economy only if it is geared toward the correction of different types of "market failures." Market failure theory (MFT) calls for specific structures for public agencies (insulation from private interests in order to avoid particular types of "governmental failures") and specific evaluation exercises (static cost-benefit analysis). The market failure justification for public intervention and associated toolkit has placed SIBs under increased scrutiny and, in some cases, criticism (e.g., Financial Times, 2012; Lisboa and Latif, 2013; Mussler, 2013), because any role beyond fixing market failures is seen as unjustified. This paper argues that the market failure framework is too limited to understand the enhanced roles that public financial institutions - and SIBs in particular-have had to play due to the increased short-termism and speculation of private finance, because it ignores the role that the state has played from the beginning of capitalism in shaping and creating markets (Polanyi, 2001 [1944]).

This paper seeks to create a typology that can explain and help us better understand the rise of SIBs. We take inspiration from the works of John Maynard Keynes (1926, 2006 [1936], 1980), Joseph Schumpeter (1934 [1912], 1939, 2002 [1912]), Hyman P. Minsky (1992, 1993; Minsky \& Whalen, 1996) and Karl Polanyi (2001 [1944]), and draw specifically on the insights from heterodox economics literatures, which can be more useful for describing the process through which public policy actively shapes and creates markets. Key concepts that we mobilize are: technological trajectories and techno-economic paradigm shifts in evolutionary economics (Dosi, 1982; Perez, 2002); mission-oriented investments in science and technology policy research (Mowery, 2010; Foray et al., 2012); developmental network state in development 
economics (Wade, 1990; Block and Keller, 2011), and the entrepreneurial state (Mazzucato, 2013a). Our contribution is the application of these literatures to the study of state investment banks (heretofore never done) and the more general use of them to propose a different lens through which to view the market creation and shaping process of public policy.

The remainder of this paper is structured as follows. Section 2 provides an historical overview of the roles that state investment banks play in the economy, through which we identify the four roles cited above: countercyclical, developmental, venture capitalist, and promotion of investments that help to address societal problems. In section 3 , we document contemporary evidence of these four roles (with a particular focus on evidence from Brazil's BNDES, the China Development Bank, the European Investment Bank (EIB), and Germany's $\mathrm{KfW}$ ), and present the market failure justification attached to each role. Section 4 discusses the implications of MFT for how SIBs' actions are structured and evaluated, and links this "diagnosis and evaluation toolkit" to key criticism to the activities of SIBs. While such criticisms highlight important issues, they are primarily the consequence of a limited perspective, and must therefore be reconsidered in order to take into account empirical evidence and alternative theories and concepts. Section 5 introduces concepts from heterodox literatures to show the limitations of MFT and to provide the basis for an alternative theoretical typology. Section 6 summarizes and contrasts the mainstream perspective with the alternative conceptualization, and reflects on the implications of the latter for the mainstream criticisms. The concluding section (7) discusses the policy implications of the alternative framework and proposes avenues for a new research agenda that goes beyond MFT.

\section{HISTORICAL OVERVIEW OF THE EMERGENCE OF MODERN STATE INVESTMENT BANKS}

The first modern state investment bank - the International Bank for Reconstruction and Development (IBRD) - has its historical roots in the monetary agreements of Bretton Woods (1944), which were decisively influenced by Keynes's ideas, and the reconstruction plans for Europe following World War II (the Marshall Plan). The IBRD was meant to promote financial stability through a permanent flow of funding for the reconstruction plan and to unleash agricultural production potential, thereby preventing the deleterious effects that the speculative, pro-cyclical private financial sector could have on the post-WWII economic recovery (World 
Bank, 2013). The IBRD made its first loan, to France, in 1947 (World Bank, 2013). Other national development banks were founded around that same time, such as the Industrial Development Bank of Canada (1944), the key goal of which was to provide "capital assistance to industry with particular consideration to the financing problems of small enterprises" (cited in Fergusson, 1948, p. 214); or the Kreditanstalt für Wiederaufbau (KfW-meaning "reconstruction credit institute") in Germany (1948), which had the aim of channelling international (and national) funds (notably those associated with the Marshall Plan) to the promotion of long-term growth, infrastructure, and modern industry (Schröder et al., 2011). Japan also created development banks. The first, in 1950, was the Export Bank of Japan (which became the Export-Import Bank of Japan in 1952), which sought to secure strategic resources to the Japanese economy and promote the insertion of Japanese firms into overseas markets. ${ }^{4}$ The second, in 1951, was the Japan Development Bank, the initial focus of which was the development of heavy industries and infrastructure (including electricity). ${ }^{5}$ Another development bank, founded a couple of years later (1953), was the Brazilian Banco Nacional de Desenvolvimento Economico e Social ${ }^{6}$ (BNDES; National Bank of Social and Economic Development), which initially promoted a catching-up (industrialization) agenda (Torres Filho and Costa, 2012). The Korea Development Bank (KDB) was founded one year later as the "Korea Reconstruction Bank," to supply and manage major industrial capital and to help develop Korean industries and economy after the Korean War. ${ }^{7}$

In subsequent decades, SIBs diversified their operations and foci. In the mid 1950s, for instance, the KfW assumed the responsibility of providing finance for environmental protection and small and medium-sized enterprises (SMEs), roles that were intensified in the 1970s, when it also began to target energy efficiency and innovation development (KfW, 2009). In the 1960s, the Japan Development Bank began to focus on financing technological development and innovation, as well as providing finance for projects that tackle environmental problems (such as atmospheric, water, and noise pollution). In 1975, the Canadian Development Bank had its

\footnotetext{
${ }^{4}$ http://www.ltic.org/Japan-Bank-for-International.html; accessed 16 June, 2014. In 1999, the Export-Import Bank of Japan (JEXIM) and Japan's Overseas Economic Cooperation Fund were merged into the Japan Bank for International Cooperation (JBIC).

${ }^{5}$ http://www.dbj.jp/en/co/info/history/index.html; accessed 16 June, 2014.

${ }^{6}$ The Brazilian development bank was founded as BNDE; it was not until the 1980s that the name was changed to incorporate an explicit "social" focus.

${ }^{7}$ https://www.kdb.co.kr/ih/wcms.do; accessed 16 June, 2014.
} 
name changed to the Federal Business Development Bank (BDC; now the Business

Development Bank of Canada) and started its venture capital operations. In the 1990s, the BDC created new financing products to promote the development of innovations. ${ }^{8}$ In 1976, South Korea founded a new development bank, the Export-Import Bank of Korea to support Korean enterprises in conducting overseas business $;{ }^{9}$ meanwhile, the KDB began to target the development of new sectors and technologies (electronics and automotive, in particular). In the 1980s, BNDES created lines of credit specifically designed for SMEs (while also helping a number of companies facing difficulties due to the Brazilian debt crisis), and in the following decade began to experiment with funding programs targeted at high-tech firms and innovation (Branco, 1994; Pinto, 1997; Pinheiro, 2000). By the 2000s, the China Development Bank (CDB), founded in 1994, was one of the most active SIBs, investing in regional economic development and industrial catching-up; supporting and nurturing new ventures and innovation; and, later in the decade, targeting finance to projects aimed at "green growth" (Sanderson and Forsythe, 2013). After the outbreak of the Global Financial Crisis in 2007, SIBs across the world significantly promoted countercyclical lending, increasing their loan portfolios by 36 percent on average between 2007 and 2009, with some (10 percent) increasing their loans by more than 100 percent (Luna-Martínez and Vicente, 2012). They were actually returning to one of the original rationales behind the establishment of the IBRD: providing financial stability throughout the business cycle.

This brief historical overview highlights four conceptually distinct roles that SIBs have played throughout their histories:

a) Countercyclical role;

b) Capital development (or developmental) role;

c) New venture support (or 'venture capitalist') role; and

d) Challenge-led role.

The contemporary evidence in section 3 shows that SIBs are (still) active across these four areas.

\footnotetext{
${ }^{8}$ http://www.bdc.ca/EN/about/overview/history/Pages/new_mandate.aspx and http://www.bdc.ca/EN/about/overview/history/Pages/until_today.aspx; accessed 16 June, 2014. ${ }^{9}$ http://www.koreaexim.go.kr/en/exim/glance/manage_01.jsp; accessed 16 June, 2014.
} 


\section{THE FOUR ROLES OF SIBS: CONTEMPORARY EVIDENCE AND THE THEORETICAL JUSTIFICATION OF MARKET FAILURE THEORY (MFT)}

In what follows, we first document contemporary evidence for each of the four roles, which, at times, also overlap. We will then present the market failure explanation and justification attached to each one. Here, we start with a brief introduction to market failure theory (MFT).

The mainstream economics perspective that explains and justifies the role of SIBs in the economy is market failure theory (MFT), which takes the "First Fundamental Theorem" (FFT) of welfare economics (Arrow, 1951; Debreu, 1959) as the starting point. The FFT states that markets are the most efficient allocators of resources under three specific conditions (Ledyard, 2008): (1) There is a complete set of markets, so that all supplied/demanded goods and services are traded at publicly known prices; (2) all consumers and producers behave competitively (all agents are price takers); and (3) an equilibrium exists. ${ }^{10}$ Under these three conditions, the allocation of resources by markets is "Pareto-optimal"; that is, no other allocation will make a consumer or producer better off without making someone else worse off. "Market failures" are said to occur when conditions (1) and/or (2) are violated; resource allocation by markets are in these situations inefficient. If markets are not Pareto efficient, then everyone could be made better off through public policies. ${ }^{11}$

Within this framework, market failure is only a necessary but not sufficient condition for governmental intervention. The sufficiency results from an assessment that the gains from the intervention outweigh the associated costs due to "government failures" (Tullock et al., 2002). Thus, there would be a trade-off between two inefficient outcomes-one generated by free markets (market failure), and the other by governmental intervention (government failure). The solutions advocated by neo-Keynesians focus on correcting failures such as imperfect information (Stiglitz and Weiss, 1981). Solutions advocated by "public choice” scholars

\footnotetext{
${ }^{10}$ Some definitions of the FFT posit that the two crucial assumptions are that markets are complete and agents are price takers, and that a Pareto equilibrium also requires the "weak" assumption of local nonsatiation of preferences. Ledyard (2008) argues that the existence of equilibrium situations are also a precondition for a Pareto-efficient allocation of resources, even though most violations of the assumption that an equilibrium exists lead to noncompetitive situations.

${ }^{11}$ There are also situations of "constrained Pareto efficiency," when public policies are unable to create a more efficient outcome than the one resulting from the competitive market, because the public authority faces the same (informational or institutional constraints) as private agents. Such a situation happens, for instance, when a public policy aims to address the lack of markets, but it unintentionally leads to non-competitive agent behavior. Such issues arising from constrained Pareto efficiency are not the same as when the policy results in "government failure" (see section 4).
} 
(Buchanan, 2003) focus on leaving resource allocation to markets (which may be able to correct their failures on their own) (see section 4.2).

Four broad categories of market failures can be described, according to the source of failure (and, hence, what needs "fixing") and which condition of the FFT it violates. As we explain next, each of these types of market failures can be associated with one of the roles that state investment banks play in the economy.

\subsection{Countercyclical Role}

Capitalist systems are marked by business cycles (Schumpeter, 1939; Perez, 2002), when periods of economic prosperity are followed by periods of recession or crisis. In times of crisis, SIBs play a crucial role, as they supply countercyclical finance (liquidity) that would otherwise be in shortage due to the higher risk-aversion of private financial institutions. Thus, public investment provides short-term fiscal stimulus to keep the economy running.

\section{a. $\quad$ Contemporary Evidence for Counter-cyclical Investments}

Banks like KfW have been supplying countercyclical finance for decades, including after the two oil crises of the 1970s, and in support of developing countries facing the "debt crisis" of the 1980s (KfW, 2009). Also BNDES played a countercyclical role in the 1980s in support of Brazilian companies affected by the debt crisis (Pinheiro, 2000). Micco and Panizza (2004) provided evidence that state-owned banks throughout the world lent countercyclically between 1995 and 2002, which coincides with the period of several economic crises (the Mexican crisis in 1994-1995, the Asian-Russian crisis in 1997-1999; the Brazilian crisis of 1999; and the Argentinean crisis of 2001-2002). When there is a crisis, the private sector retreats and the public sector steps in - as happened again during the global financial crisis of 2007. Therefore, this role is not new per se. However, as we will see below, this kind of counter-cyclicality has been increasingly intertwined with the other roles of SIBs (provision of long-term funding), being directed towards innovations or tackling grand societal challenges, such as climate change.

The countercyclical role became evident in the last economic crisis (2007-2010), when SIBs were best positioned to promote countercyclical lending to key sectors of the economy, because they were already familiarized with markets and clients, staffed with experienced professionals, and had the financial capacity to respond to the credit crunch in a timely fashion 
(Luna-Martínez and Vicente, 2012). The EIB, for instance, played a critical role in 2008-2009 in sustaining investments to promote growth and employment in Europe. It expanded loans from $€ 47.8$ billion in 2007 to $€ 57.6$ billion in 2008, and to $€ 79.1$ billion in 2009 (Griffith-Jones and Tyson, 2012) - a 65-percent increase from the pre-crisis level. In developing countries, too, SIBs stepped up to counter the credit crunch. In Latin America, whose central banks were prevented from directly intervening in financial markets (quantitative easing a la FED), national and regional SIBs filled the vacuum and increased their assets by 30 percent (Gutierrez et al., 2011). The China Development Bank (CDB) also played a key role in stimulating the economy so that China could "continue its growth spurt through the global financial crisis" (Sanderson and Forsythe, 2013, p. xvi).

In Brazil, the availability of credit was particularly impacted by the crisis, as a consequence of the net decline in capital flows to emerging markets and the repatriation of investments (Kregel, 2009). As a result, both domestic and foreign financial institutions rationed credit to Brazilian industry. Instead of downplaying its industrial policy plan, the Brazilian government stepped it up through the Program for the Sustainability of Investments (PSI), which augmented tax incentives and the availability of credit by transferring resources from the Treasury to BNDES (Bastos, 2012). This decision resulted in increased disbursements by BNDES (Figure 2), including the supply of short-term finance (e.g., working capital) for companies facing liquidity problems. In order to promote innovation investments, BNDES also lowered interests of its main line of credit for innovation to 3.5 percent per annum and increased the terms of payment to 120 months (BNDES, 2012). Even though innovation investments in dollars increased in 2008 (in absolute and relative terms), the boost in the supply of short-term, countercyclical finance (e.g., working capital) meant that in 2009-10 investments in innovation declined as a percentage of total disbursements, but thereafter they increased again and reached 2.74 percent in 2013 (Figure 3). 
Figures 2 and 3 BNDES's Total Disbursements and Disbursements for Innovation

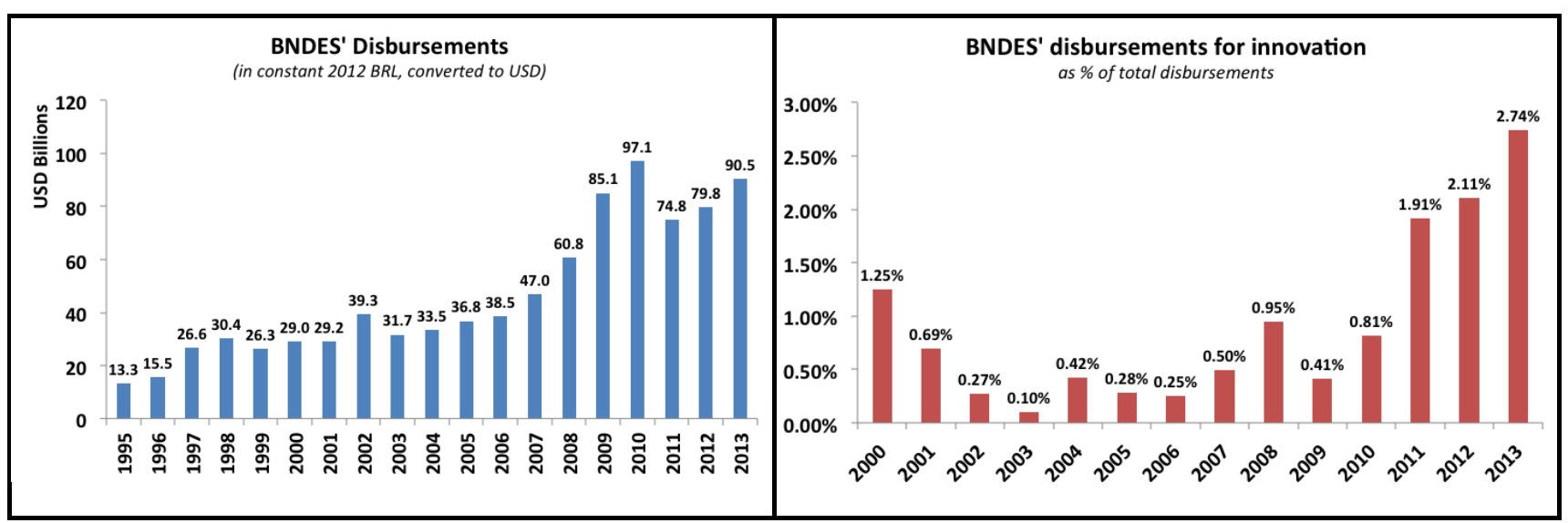

Sources: Figure 2 based on data from BNDES annual reports and Giambiagi et al. (2009). Innovation data obtained from BNDES.

In Germany, KfW also played the countercyclical role, as part of the German (federal) government economic stimulus packages. In 2008, KfW launched its "Special Programme," which sought to address the issue of low private investments that resulted in industrial capacity utilization being below historical lows $(1975,1982,1993)$ (KfW, 2010). The Special Programme, which was to be executed mainly by KfW's subsidiary, Mittelstandsbank (which focuses on funding for SMEs, including venture capital), concentrated on the supply of finance ( $€ 40$ billion in working capital and other liquidity measures), but KfW also provided more funding for innovation, infrastructure, commercial investments, environmental protection, energy efficiency and rehabilitation (see Table 1). With the phase-out of the Special Programme in 2011, KfW's trade and industry investments declined by 21.7 percent, returning to the precrisis level (KfW, 2012). Figure 4 shows the evolution of disbursements by KfW Mittelstandsbank in the past decade, which highlights the significance of the Special Programme in 2009 and 2010. 
Table 1 Four KfW Components of the Stimulus Packages

\begin{tabular}{|l|l|l|}
\hline Four KfW components & $\begin{array}{l}\text { Description } \\
\begin{array}{l}\text { 1. Corporate financing, } \\
\text { particularly to SMEs }\end{array}\end{array}$ & $\begin{array}{l}\text { Volume of lending } \\
\text { (forecasted) }\end{array}$ \\
\hline $\begin{array}{l}\text { 2. Energy-efficient } \\
\text { construction and } \\
\text { rehabilitation }\end{array}$ & $\begin{array}{l}\text { - Stepping up the existing programs for } \\
\text { energy-efficient construction and } \\
\text { rehabilitation } \\
\text { - New programme: Senior-friendly } \\
\text { conversions }\end{array}$ & $€ 8.5$ billion \\
\hline $\begin{array}{l}\text { 3. Innovation and energy- } \\
\text { efficiency of enterprises }\end{array}$ & $\begin{array}{l}\text { - Stepping up existing programmes: } \\
- \text { ERP Innovation Programme } \\
- \text { ERP Energy Efficiency Programme } \\
- \text { ERP Start Fund } \\
\text { - New programme: } \\
- \text { KfW Programme Renewable Energies } \\
\text { (supplement) }\end{array}$ & $€ 1.0$ billion \\
\hline 4. Infrastructure & $\begin{array}{l}\text { New programme: Investment Offensive } \\
\text { Infrastructure }\end{array}$ & $€ 3.0$ billion \\
\hline Total & & \\
\hline
\end{tabular}

Source: KfW (2010, p. 43).

Figure 4 KfW Mittelstandsbank's Disbursements by Type

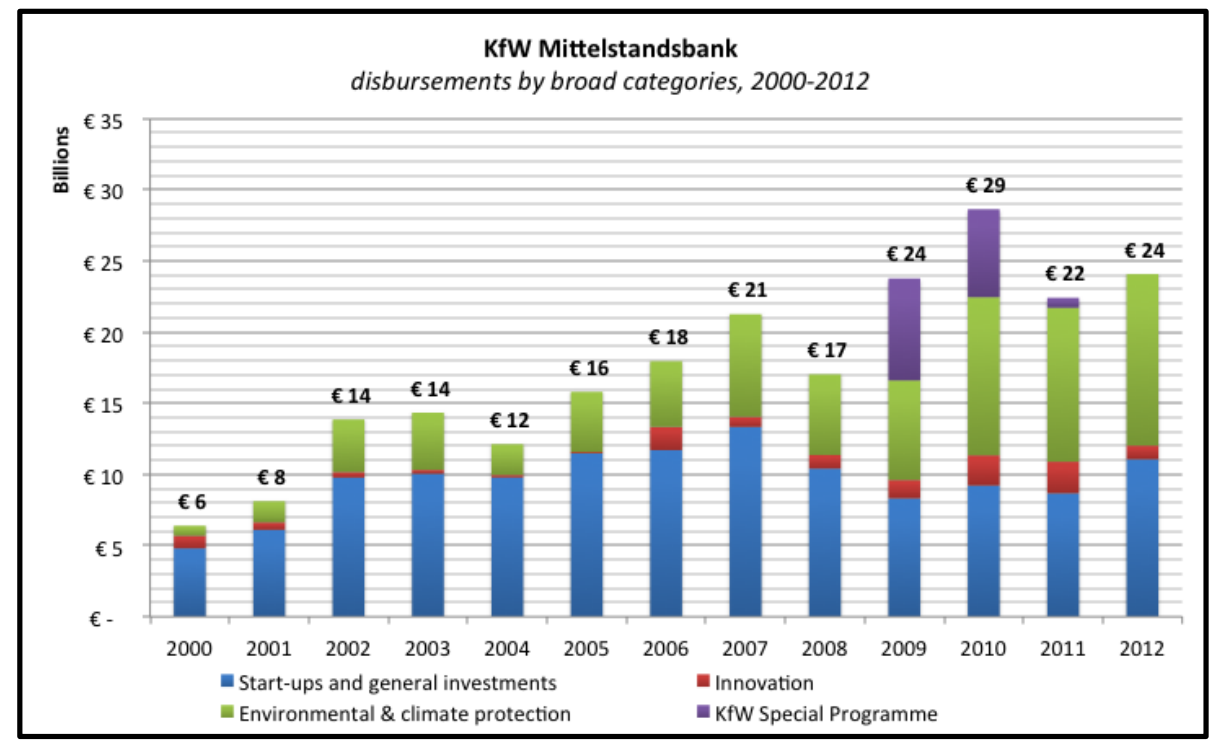

Source: Data from KfW's annual reports

\section{b. Market Failure Theory Justification for Countercyclical Investments}

The MFT justification of the countercyclical role is based on the notion that business cycles

create an intertemporal dynamic that leads to situations in which the economy follows a Pareto- 
inefficient path (Stiglitz, 1974; 1991). In such situations, capital, labor, and natural resources will be underutilized. Such coordination failures occur when agents are unable to coordinate their expectations and preferences throughout the business cycle, due to information asymmetries and high screening costs (agents do not know each other's set of preferences and expectations, and the cost of obtaining this information through screening the market is too high), or issues of free-riding (agents do not change their preferences/expectations for fear that other agents will benefit from their actions). Both cases can be shown to violate the first condition of the FFT of welfare economics: there are no markets for information or for the externalities generated by an agents' decisions to change their preferences. Thus, markets will either not reach an equilibrium, or will reach a Pareto-inferior (suboptimum) equilibrium: supply will not match demand, workers will not find employment (unemployment equilibrium), and new purchasing power and savings will not get invested.

From this perspective, the countercyclical role of SIBs would be a way to address a particular type of coordination failure that arises from private agents (such as banks and firms) being too pro-cyclical (lending and investing too much in the boom and too little in the bust), putting the economy on a downward path, and not realizing that by increasing lending, they would be helping the economy out of recession (Levy-Yeyati et al., 2004). Therefore, MFT assumes that SIBs are "risk-neutral" and capable of absorbing risk during an economic crisis, spreading risk over time and cross-sectionally (Arrow and Lind, 1970; Gutierrez et al., 2011). It is this assumption that justifies the countercyclical role of SIBs. For instance, in times of crisis, greater risk aversion of private agents may lead to underinvestment. To address this issue, SIBs may increase public investment to provide short-term fiscal stimulus to keep the economy running (Mankiw and Romer, 1991). Their investments signal to the other agents confidence on the economy (thus addressing information asymmetries and issues of screening) and/or generate a positive externality to other agents (e.g., increase in effective demand).

\subsection{Capital Development (or Developmental) Role}

SIBs also play important roles during periods of economic boom, promoting strategic investments for economic development. This was one of the original roles of many multilateral and national development banks, such as the IBRD (World Bank), JDB, KDB, BNDES and $\mathrm{KfW}$. It is also the key role performed by export-import banks. Therefore, this role is not exclusive of SIBs from developing countries engaged in industrial catching-up, as could be 
expected. Indeed, despite Germany’s status as a developed economy, KfW still plays a developmental role (see below), and the original funds from the Marshall Plan still revolve around and are invested in promotional areas (KfW, 2009). Also the United States, usually portrayed as the free-market economy par excellence, has an active export-import bank that, for eight decades, has supported the country's exporting sector.

\section{a. $\quad$ Contemporary Evidence for Capital Development Investments}

Today, the China Development Bank (CDB) is the prime example of an SIB playing the capital development role, as it is the key financier of China's five-year strategic plans. In the last two decades, CDB has "provided the capital and investment for China's economy to catch up from a starting point without a modern banking system, small stock and bond markets" (Sanderson and Forsythe, 2013, p. 177). Since 1994, CDB has financed infrastructure and urbanization projects to the tune of more than US\$2 trillion (idem). Brazil is another country whose SIB visibly plays the capital development role. BNDES is the main source of "patient" capital (funding) for longterm projects that are not financed by private initiatives. Even with the flourishing of a domestic capital market in recent decades, the private financial sector (particularly commercial banks) has concentrated on supplying credit to household consumption and short-term credit to firms, for which it could charge high interest rates with relatively little risk. Moreover, instead of funding long-term projects, private investment banks have tended to invest in Brazilian government bonds, which offer high yields and high market liquidity (Kregel, 2009). Indeed, Brazilian private commercial banks' loan portfolios are concentrated on loans with terms of less than five years (75 percent). In contrast, BNDES's portfolio is made up of 37 percent credit operations with 5-15 years of maturity, and 9 percent with more than 15 years (Portugal, 2013).

The Brazilian private financial sector's retreat from providing long-term funding for infrastructure and industry projects has meant that BNDES has historically concentrated its disbursements on these sectors, a trend that has continued in recent decades (Figure 5). In fact, over the last decade, credit from BNDES was, on average, second only to retained earnings as a source of funding for industry and infrastructure (Figure 6), while domestic private sector funding (equity and bonds) contributed with 16 percent on average. Figure 6 also shows the importance of BNDES's countercyclical action directed towards industry and infrastructure during the crisis, particularly in 2009, when it became the most important funding source for capital development projects. 
Figures 5 and 6 BNDES Disbursement by Sector and Sources of Long-term Funding in Brazil

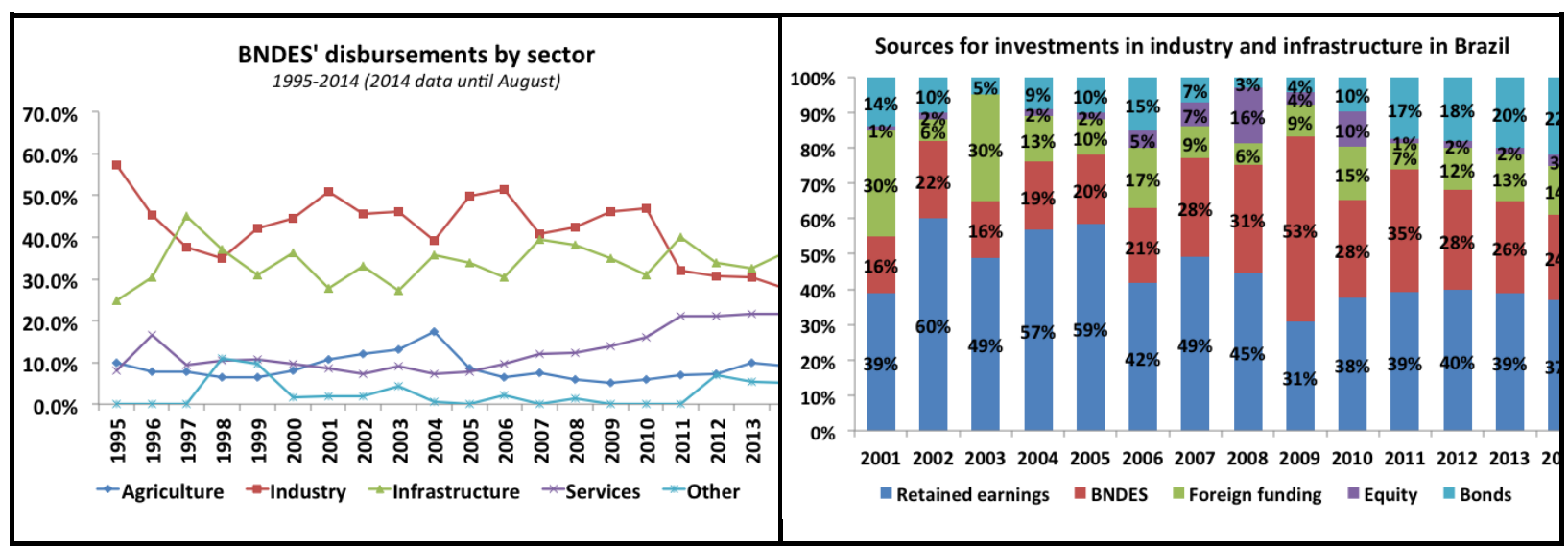

Sources: Figure 5 based on data from Giambiagi et al. (2009) and BNDES' financial reports, and Figure 6 on data from Costa (2011) and BNDES' financial reports.

While the United States does not have a development bank (SIB) as such, ${ }^{12}$ since 1934, it has had an export-import bank (the US Ex-Im Bank), which became an independent executive agency in 1945. It supplies finance to export companies (direct loans) and funding for capitalintensive sectors, such as aircraft, oil drilling and nuclear power equipment (Adams and Williams, 2010). Furthermore, it also provides insurance and long-term loan guarantees. In its eight decades of existence, the US Ex-Im Bank has supported more than \$567 billion of US exports. $^{13}$

In Germany, KfW continues to supply funding for the capital development of the economy, in the form of funding/finance for infrastructure projects, exports, housing, etc. For example, KfW's independent subsidiary, KfW IPEX-Bank, provides project finance and export finance to promote competitiveness and internationalization of German companies, including big corporations like Airbus. ${ }^{14}$ Figure 7 shows KfW IPEX-Bank's new commitments by business sector, both in Germany and abroad. While detailed figures for KfW IPEX-Bank's domestic commitments are not available, an average of 30 percent of the bank's commitments

\footnotetext{
${ }^{12}$ In 2008, President Obama backed a Senate proposal for the creation of a National Infrastructure Reinvestment Bank - to date, the bill has not yet been voted upon.

${ }^{13} \mathrm{http}: / /$ www.exim.gov/about/; accessed 16 June, 2014.

14 The IPEX-Bank provides finance for the acquisition of Airbus aircrafts.
} 
were in Germany in 2008-2012, which represents approximately $€ 3.3$ billion per year, with 38 percent invested in the rest of Europe and 32 percent in other regions. ${ }^{15}$

Figure 7 KfW IPEX-Bank New Commitments by Business Sector

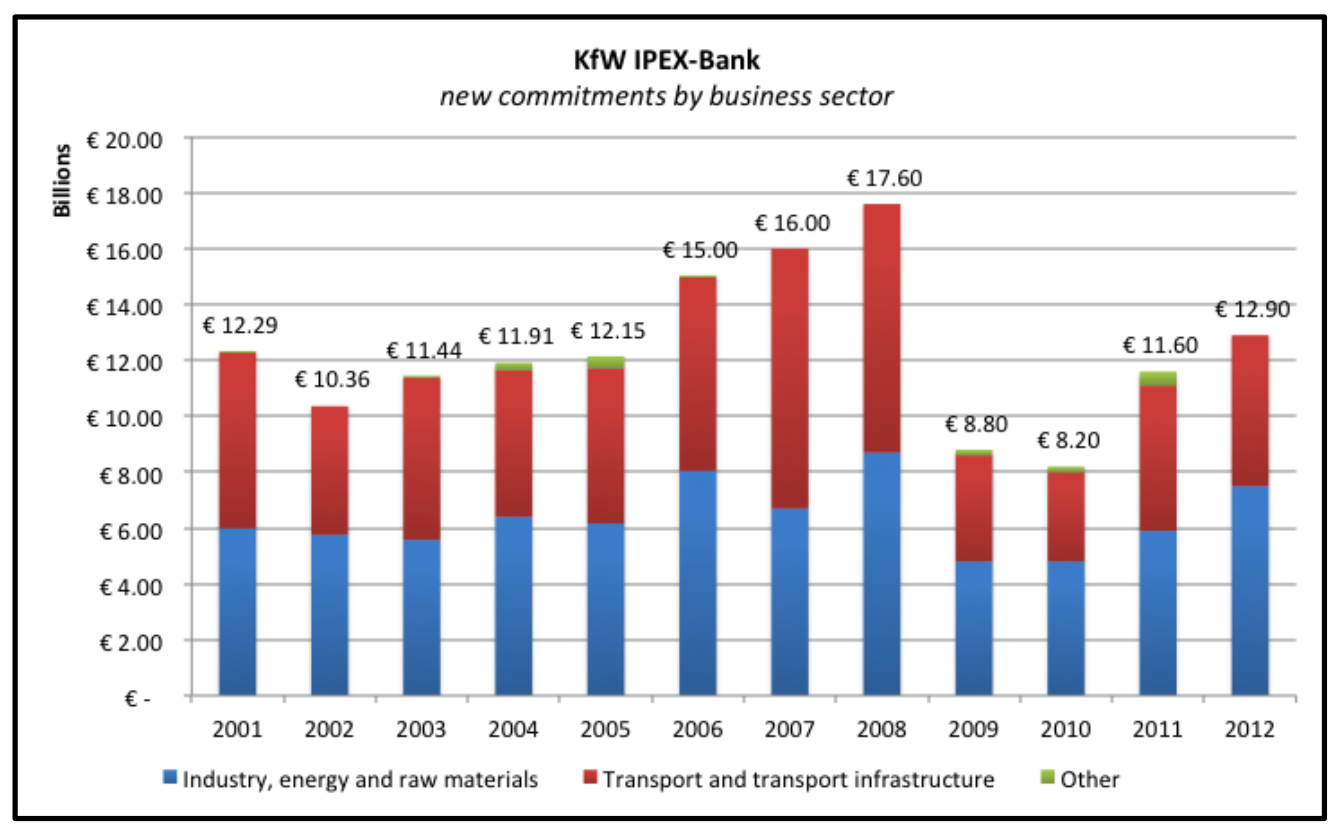

Sources: Based on data from KfW's annual reports.

Note: In 2009, accounting of IPEX-Bank's commitments by KfW changed due to IPEX-Bank becoming a legally and financially independent subsidiary.

\section{b. Market Failure Theory Justification for Capital Development Investments}

Wherever private lenders have limited incentives to finance projects with "public good" characteristics (non-excludable and non-rival; often portrayed as instances of positive externalities), or in situations of imperfect competition, the market is not an efficient allocator of resources. These situations violate conditions (1) and (2) of the FFT, respectively, justifying public investments (through SIBs, for instance). Examples include private markets underfunding of goods with very high spillovers or socially desirable infrastructure projects with positive externalities; both are characterized by value that cannot be internalized by private agents. $R \& D$ investments generate new knowledge, which cannot be fully appropriated by the original investor (who cannot "exclude" other agents from using the knowledge to their own benefit). Thus, private agents tend to underinvest in R\&D and innovation, because they cannot internalize benefits that would compensate for the development costs and make the investments worthwhile. Market failures associated with industry structures ("competition failures") are

\footnotetext{
${ }^{15}$ Our calculation based on data from KfW's annual reports.
} 
another rationale for the developmental role of SIBs. Competition failures arise when there are high natural barriers to entry (due to scale economies or network effects), which also lead to Pareto-inefficient situations (Stiglitz, 1991). SIBs provide funding in situations of monopoly and monopsony, in order to promote entry of new agents, increase the pool of producers and consumers, respectively, and foster competition. The particular case of support for exporting activities may be subsumed to a case of positive externalities (for which there are no markets), such as in cases where exports generate technological spillovers and learning (through the testing of goods and services in foreign markets). Another market failure rationale for supplying export credit is to absorb risk that private financial actors are unable or unwilling to accept, a situation that violates FFT's condition (1) (markets for risks are incomplete). A final rationale for the support of exporting activities is to "level the playing field" and promote "competitiveness": to match financing and funding conditions that other governments provide to their own exporters, thus promoting competition in world markets. ${ }^{16}$ Thus, supporting the production of public goods and positive externalities (for example, provision of clean air or new knowledge) and addressing situations of imperfect competition (for example, natural monopolies, network effects, supply and demand-side economies of scale) are both key reasons for industrial policies and the associated capital development role of SIBs.

In order to correct for these kinds of market failures, the state may implement horizontal policies to promote early-stage blue sky research, infrastructure and other public works, enforce competition policies, regulate natural monopolies, establish early technical standards, provide export credit, and so on. What also links those sources of failures is that they all focus on using macro industrial policies to promote investments in public goods that are under-produced in prevailing market conditions or to tackle situations of monopoly and monopsony. As the evidence presented above has indicated, SIBs are often the lead funding agent behind macroindustrial policy plans, both in developed and developing countries. SIBs sometimes fulfil their developmental role by promoting investments that seek to create a "national champion," which is at odds with the goal of addressing market failures due to non-competitive behavior and may lead to a constrained Pareto efficiency equilibrium. Nonetheless, this is a type of investment that seeks to promote the entry of a new producer in the world market (see section 5).

\footnotetext{
${ }^{16}$ We thank Lavinia Barros de Castro for stimulating us to expand on the market failure rationales for the support of exporting activities.
} 


\subsection{New Venture Support Role}

Investment in new ventures, such as SMEs and innovation development, has been the focus of some SIBs since the 1950s, but these activities have been intensified more recently, particularly the support for innovation (KfW, 2009; Griffith-Jones and Tyson, 2013; BNDES, 2012). Underlying the initiative is the fact that SMEs face difficulties in securing external funding due to a lack of guarantees and collaterals or of a track record of profitable investments. Innovation development also presents problems in securing external funding, due to the economic and technical risks and uncertainties that underlie the innovation process.

\section{a. Contemporary Evidence for Venture Investments}

In industrialized economies, SIBs are particularly important in helping to address the SME "funding gap," whereby small enterprises, specifically start-ups that are highly innovative, lack both internal and external sources of funding for innovative projects (Griffith-Jones and Tyson, 2013). In Europe, the European Investment Bank (EIB) created the European Investment Fund (EIF) in 1994, which is dedicated to SME and venture capital investment. ${ }^{17}$ In 2009 , when the EIB was engaged in countercyclical lending, 19 percent of its total funding went to SMEs (Griffith-Jones and Tyson, 2012). In Germany, SMEs in general report difficulties in securing external financial sources, but the problem is more acute for young high-tech firms (Tchouvakhina, 2013).

Therefore, another aspect of the funding gap is connected to innovation. Many SIBs have programs that do not target small firms per se, but rather those firms that are most innovative and engaged in technological development. KfW has a long tradition of providing venture capital to start-up firms developing new technologies (see Figure 8, which shows KfW's venture capital investments in the past decade). For instance, KfW's High-Tech Start-Up Fund provides venture capital to young technology companies in their seed phase (defined as its first year of existence), with the aim of supporting innovation efforts until the proof-of-concept phase (product prototype) or even the proof-of-market phase (product launching) (KfW, 2012). The ERP Start-Up Fund provides venture capital to young companies that have passed the first stages of development, and it is designed to complement the EIB's Investment Fund and Angels

\footnotetext{
${ }^{17}$ See http://www.eif.org/, accessed on 29 October 2013.
} 
Fund, in that it can match funding provided by EIB (KfW, 2012). Between 2008 and 2012, the ERP Start-Up Fund invested an average of $€ 68$ million per year.

Figure 8 KfW's Venture Capital Investments, 2002-2012

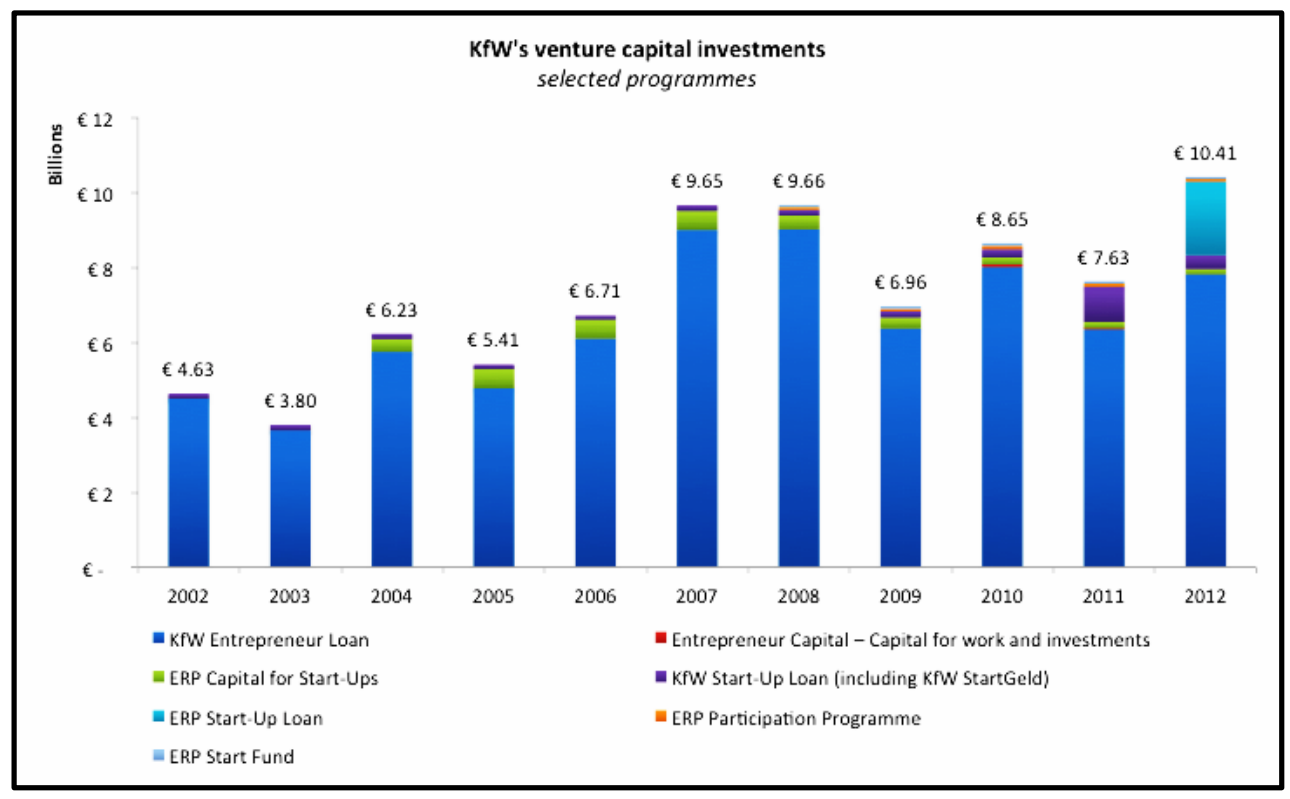

Sources: Based on data from KfW's annual reports.

To finance innovative start-ups, the China Development Bank founded CDB Capital, a public equity fund with 35 billion yuan (c. US\$ 5.76 billion) in seed capital (Sanderson and Forsythe, 2013) that is used to fund high-tech companies (such as telecom firms like Huwaei). At BNDES, equity investments are executed by its full subsidiary, BNDESPAR, which in recent years has started to invest in young and innovative companies. ${ }^{18}$ According to data published in Mattos (2008), BNDESPAR holds direct investments in approximately three dozen small and mid-sized innovative companies. One-third of these are ICT and electronics companies and another 15 percent are biotech or biopharma companies. The data also show that BNDES has invested in nanotech, defense, and medical equipment companies, among others. Since 2008, a significant portion of BNDES's equity investments have happened through the CRIATEC investment fund, which supplies seed capital for innovative start-up companies that develop disruptive technologies in high-tech and new sectors. CRIATEC establishes a clear link between risk sharing and reward sharing, as it "aims to achieve capital gains through long-term

\footnotetext{
${ }^{18}$ Support for "technical change" and technological catching-up has existed at BNDES since the 1960s, but such activity was more akin to a capital development role.
} 
investment in early-stage companies (including 'zero stage') that have an innovative profile and [offer] high-return prospects."19

Another part of BNDES's support for research and development with commercial (innovative) potential consists of non-reimbursable funding (grants). BNDES reserves 1.5 percent of its profits ${ }^{20}$ to the technology fund FUNTEC, which is dedicated to supporting science and technology (S\&T) institutions engaging in applied research, technological development, and innovation. FUNTEC has several goals, particularly the development of innovative solutions to promote the environmentally sustainable development of Brazil (BNDES, 2012) — it therefore contributes directly to BNDES's challenge-led role as well. Criteria for selecting projects include the degree of technological challenge, innovativeness, and potential application of the technology across sectors. FUNTEC resources are targeted toward specific technologies/sectors, which are defined on an annual basis. In 2012, the list of targets were: (1) alternative energy, specifically bioenergy (such as new-generation biofuels), solar energy, and thermal energy; (2) nanotech and biotech solutions to address issues of waste disposal and land and water pollution; (3) bio-electronics, specifically organic electronics and other innovative integrated circuits; (4) new materials; (5) biochemistry; and (6) electric-drive vehicles and technologies for the production, charging, and storage of electricity in automotive vehicles. Although FUNTEC is marginal, given its size, it represents a radical departure from BNDES's traditional role of promoting investments in infrastructure, capital development, and catching-up projects. It is a project to make Brazil a first-mover in radically innovative sectors to promote smart (innovation-led) and sustainable (low-carbon) growth, which is only possible when BNDES is successful in and profits from its other investments.

\section{b. $\quad$ MFT Justification for Venture Investments}

The MFT justification of the new venture support or venture capitalist role is related to market inefficiencies at the micro level. An example is information failures arising from incomplete markets with high transaction costs and information asymmetries, such as unavailability of public information on bad vs. good borrowers (leading to adverse selection or moral hazard behaviors). Such market failures create inefficiencies associated with non-equilibrium situations

\footnotetext{
${ }^{19}$ See http://www.fundocriatec.com.br/, accessed on 12 June, 2013.

${ }^{20}$ The percentage is shared with other social, cultural, and economic research funds.
} 
that result from the interaction between agents (microeconomic exchanges). For example, microeconomic Pareto inefficiencies may be caused by information asymmetries that lead to an adverse selection of potentially good borrowers (Stiglitz and Weiss, 1981); or they may be the result of high costs to carry out a transaction through markets (Coase, 1960). The classic example is the lack of finance/funding for small enterprises and start-ups, which usually lack a track record of good borrowing behavior and are unable to offer guarantees for debt contracts. Another example is the lack of funding for $\mathrm{R} \& \mathrm{D} / \mathrm{innovation}$ projects, which are risky and uncertain. Underinvestment in R\&D projects due to information asymmetries ${ }^{21}$ can even occur in the presence of strong intellectual property laws, macroeconomic stability, free trade, and contract enforcement, because markets are "incomplete" - there is no market for informationand agents may be stimulated to free-ride on each other's efforts (Stiglitz, 1991; Rodrik, 2004). In these situations, SIBs' investment in SMEs and innovation, through loans, equity, or grants, would be justified in order to promote economic diversification, growth, and development.

\subsection{Challenge-led Role}

In identifying SIBs' challenge-led role, we take inspiration from science, technology, and innovation (STI) studies that looked at mission-oriented policies (see, for instance, Mowery, 2010; Foray et al., 2012). Mission-oriented are those kinds of policies that target the development of particular technologies that address a given societal challenge, such as "putting a man on the moon," in the case of Project Apollo. As explained in section 2.1, the missionoriented literature developed many useful empirical studies and insights, but it has been limited to the analysis of agencies that focus on science, technology, and innovation policies, and finance STI projects through non-reimbursable funding. Indeed, most studies in a recent special issue of the journal Research Policy (Volume 41, Issue 10) on historical mission-oriented policies looked at quite particular types of non-reimbursable public finance for basic research, such as grants, subsidies (including tax credits), and innovation prizes. Given this limited focus, the literature overlooked the rise of state investment banks as sources of missionoriented/challenge-led funding, a trend to which we turn now.

\footnotetext{
${ }^{21}$ As explained above (section 3.2), R\&D projects may also be underfunded because the knowledge they generate is a public good. Therefore, R\&D projects suffer with market failures both at the micro and macro levels.
} 


\section{a. $\quad$ Contemporary Evidence for Challenge-led Investments}

The challenge-led role of SIBs is informed by missions pre-defined in bold public policy plans, such as Germany's “energy turnaround" (Energiewende), which seeks to phase out nuclear energy and fossil fuels, and substitute them with renewable energy sources in order to tackle climate change, protect the environment (save resources), and promote energy security and safety. Other challenges that SIBs are tackling around the world are economic integration of underdeveloped regions and promotion of smart growth (BNDES), demographics and globalisation (KfW and EIB), and the transition to a green economy (development banks of China and Korea). Here we concentrate on presenting evidence pertaining to their investments in projects aimed at addressing climate change (investments in renewable energy and energy efficiency).

Relatively well-established green energy technologies, such as solar, wind, and biofuels, which first received development impetus following the 1970s energy crisis, still require the active support of governments for patient long-term committed funding (Mazzucato, 2013a). Indeed, in the emerging green economy, too little private money is going into the most capitalintensive and high-risk areas of renewable energy (Ghosh and Nanda, 2010). The few investments that have been made in this area have diminished since the financial crisis of 2007 (FS-UNEP/BNEF, 2013; Geels, 2013). There is increasing evidence that since 2007, it has been SIBs that have been making the core investments in clean energy projects (Climate Policy Initiative, 2013). Figure 9 shows how SIBs have trebled their investments in renewable energy between 2007 and 2011. Figure 10 breaks up investments in renewable energy by project type.

Figures 9 and 10 State Investment Banks' Financing for Clean Energy and Renewable Energy

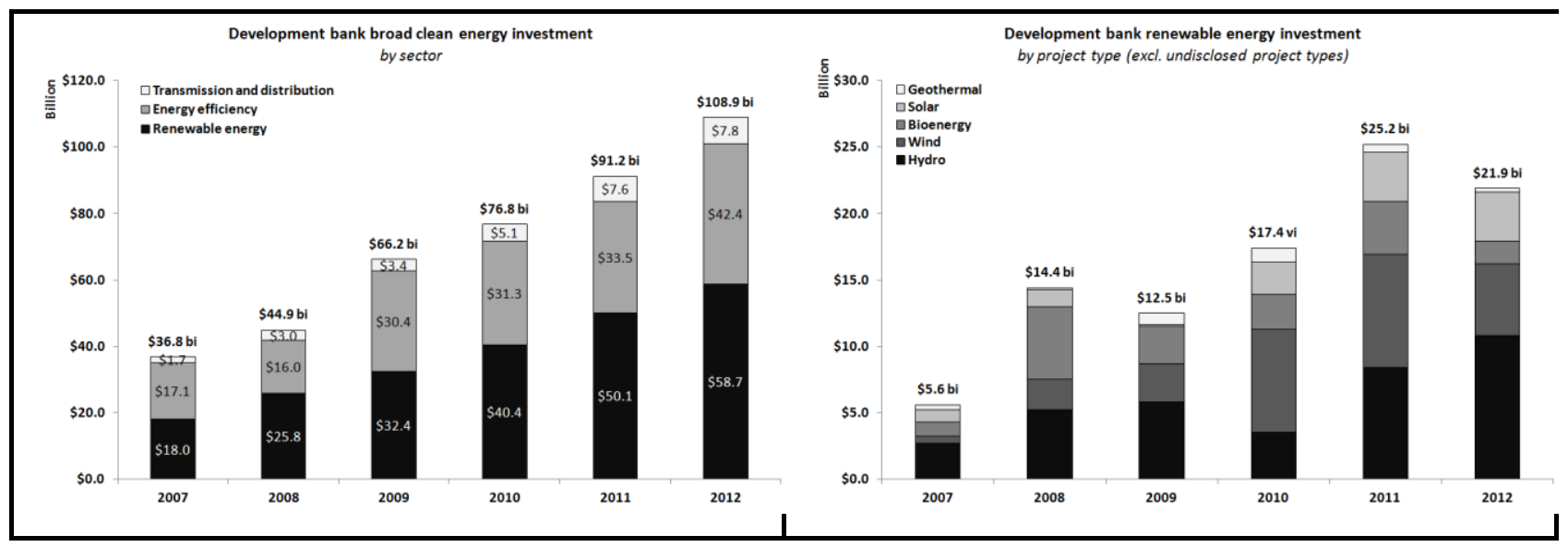

Source: Based on data from FS-UNEP/BNEF (2013). 
Some SIBs, such as BNDES, CDB, EIB and KfW, are particularly active in promoting green energy investments. In Brazil, BNDES supplies mission-oriented funding for applied research and development projects through targeted "sectoral"” programs (Schapiro, 2012). For instance, the so-called PAISS program aims to reposition Brazil in the race for cellulosic ethanol. BNDES estimates that, by 2021, investments to fully diffuse the technology (and substitute for first-generation production methods) will require $\$ 60$ billion, which will lead to net savings in planted area (and indirectly save carbon emissions from deforestation) and to a 60-percent increase in efficiency in the use of sugar cane crops (Ramundo, 2013). BNDES also takes part in the Business Innovation program established by the federal government as part of the most recent industrial policy plan (Plano Brasil Maior; PBM), which targets innovation in strategic areas with a higher risk profile and aims to develop a green economy in Brazil (Brazilian Ministry of Finance, 2012). One of the areas is energy innovation, which focuses on renewable energy, for which BNDES (together with FINEP, the Brazilian agency for financing innovation projects and R\&D) will supply $\$ 2.8$ billion (Ramundo, 2013). Another area is Environment (greentech), which will receive another \$1 billion in investments from BNDES. In addition, BNDES funds cutting-edge technology development projects in the areas of alternative energy, nanotech, biotech and electric-drive vehicles through the FUNTEC (see section 3.3). BNDES's investments in the green economy and for environmental and climate protection have increased tenfold since 2000 (Figure 11). The bulk of BNDES's "green" investments goes to renewable energy projects, which amounted to USD \$3.5 billion per year on average in 20082013 (the figure excludes investments in large hydroelectricity power plants), but also includes investments for the renewal of public and cargo transport fleets (more fuel efficient vehicles); green agricultural projects; waste, water and forest management; energy efficiency; and climate change adaptation projects. 
Figure 11 BNDES's Green Investments

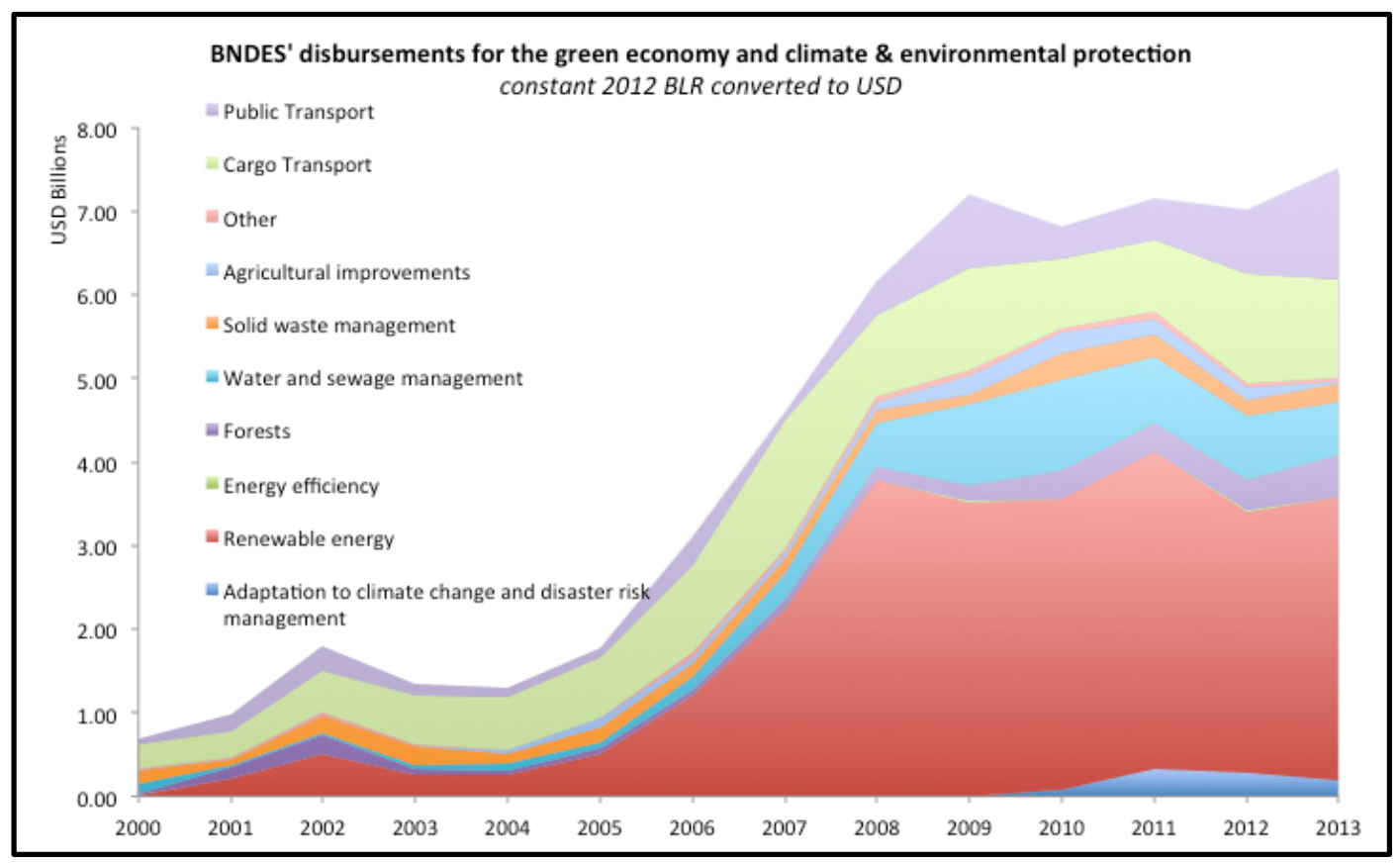

Source: Data supplied by BNDES.

The CDB has a track record of funding alternative energy firms to develop their technologies, such as the solar company Yingli Green Energy, which received approximately US \$1.7 billion from 2008 through 2012 and has a US \$5.3 billion line of credit opened for it at CDB (Sanderson and Forsythe, 2013). Since 2010, the CDB has made available US \$47.3 billion in credit lines for Chinese wind and solar energy companies and another US $\$ 30.6$ billion for clean energy transmission, distribution, and efficiency investments. In 2010, the list of Chinese alternative energy technology companies receiving CDB lines of credits included LDK Solar (US \$9.1 billion), Sinovel Wind (US \$6.5 billion), Suntech Power (US \$7.6 billion) and Trina Solar (US \$4.6 billion), which "allowed Chinese companies to further ramp up production and drive down costs" of renewable energy technologies (Sanderson and Forsythe, 2013, p. 151). Thus, CDB is a key element in China's mission of producing 20 percent of its energy from renewables by 2020 .

Since the establishment of the EU 2020 strategy, the EIB has increased its commitments to new sectors such as renewable energy, and supported the modernization of European energy grids to facilitate transmission of renewable energy sources. Furthermore, it has promoted energy efficiency in housing and the development of "smart cities," where advanced 
infrastructures substitute for carbon-dependent ones. ${ }^{22}$ EIB's 2010-2012 Operational Strategy defined environmental protection and sustainable development as key focal objectives. In accordance, the EIB stepped up its investments in climate protection projects. In 2010, EIB's investments for climate action reached $€ 20.5$ billion, including $€ 4.1$ billion for greentech $R \& D$, $€ 6.2$ billion specifically for renewable energy, and $€ 7.9$ billion for sustainable transport (such as electric vehicles and related infrastructure). In 2012, EIB launched the pilot phase of the Europe 2020 Project Bond Initiative, which aims to stimulate investment in key strategic EU infrastructure in transport, energy and broadband. The EIB committed $€ 230$ million to the initiative, which will enable it to provide funding to infrastructure projects worth more than $€ 4$ billion. Amongst the first projects funded through the initiative are new grid connections to several offshore wind farms in the UK and Germany. The EIB's investments also targeted the development of radical low-carbon innovations. In 2009, these investments included financing the R\&D of electric and energy-efficient cars and of wind turbines (Table 2), each carried out by leading private companies. In 2012, EIB announced a €180-million loan to the Renault Group for the development of new generation of batteries and motors for electric vehicles.

Table 2 Examples of Cutting-edge Projects Financed by EIB in 2009

\begin{tabular}{|l|l|l|l|}
\hline Project description & Countries & Private sector partners & $\begin{array}{l}\text { Investment } \\
\text { size }\end{array}$ \\
\hline $\begin{array}{l}\text { R\&D of Electric \& energy- } \\
\text { efficient cars and related } \\
\text { infrastructure }\end{array}$ & $\begin{array}{l}\text { Germany, France, } \\
\text { UK, Spain }\end{array}$ & $\begin{array}{l}\text { BMW, Daimler, Renault, } \\
\text { Nissan }\end{array}$ & $€ 1.3$ billion \\
\hline R\&D of wind turbines & Denmark & Vestas Wind Systems & $€ 250$ million \\
\hline
\end{tabular}

Source: Griffith-Jones and Tyson (2013).

In Germany, KfW has a long tradition of investing in the development of green innovation and in the modernization of industries, urban infrastructure, and housing to promote the reduction of $\mathrm{CO}_{2}$ emissions through the use of new technologies. Figure 12 depicts the trend in KfW's investments in environmental and climate protection projects in Germany from 2000 to 2013, showing that the level of investments increased 5-fold in the period. In addition to its funding programs, KfW provides advice and covers costs associated with expert advice, a service-side coordinating measure that seeks to motivate existing firms to invest in energy

\footnotetext{
${ }^{22}$ In 2010 , it committed $€ 14.7$ billion to sustainable cities projects such as transport and urban renewals (GriffithJones and Tyson, 2013).
} 
efficiency by countering their lack of information on savings potential or ability to use renewable sources.

Figure 12 KfW's Investments in Environmental and Climate Protection Projects in Germany

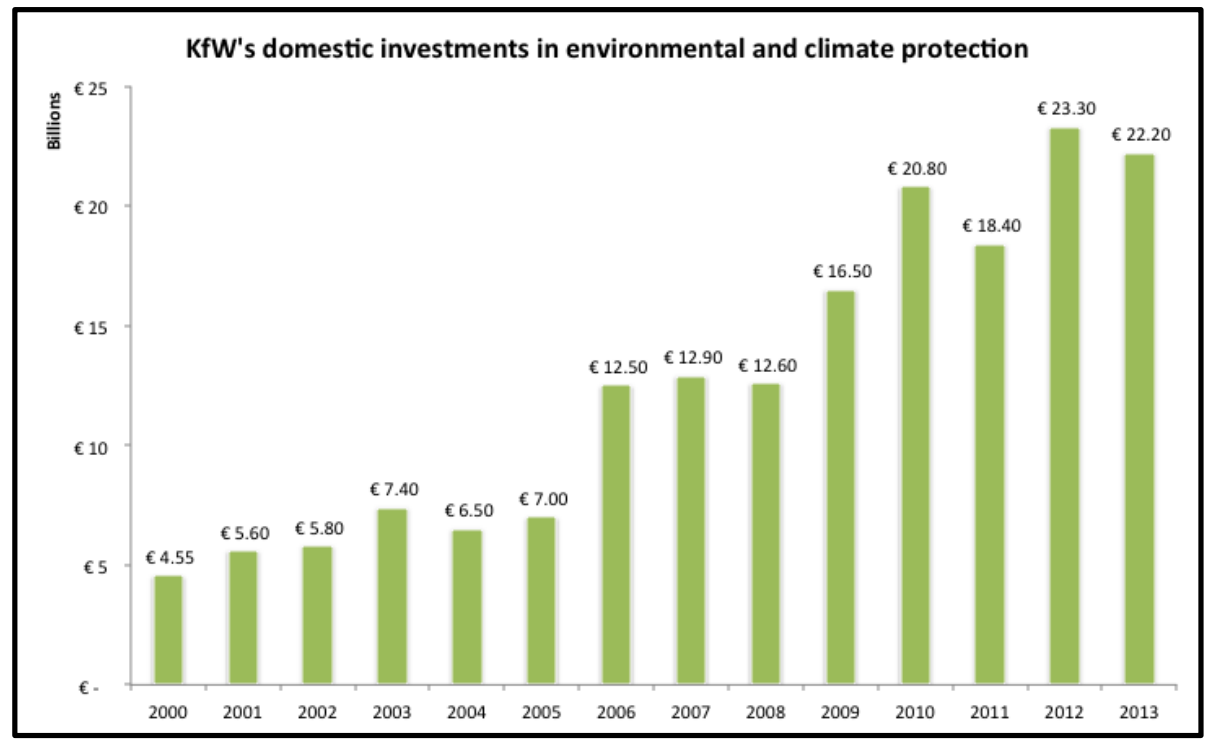

Source: Based on data from KfW's annual reports.

\section{b. $\quad$ Market Failure Theory Justification of Challenge-led Investments}

Such kind of investments to tackle societal challenges is often justified through MFT, as they seek to address negative externalities arising from the production or use of goods and services such as climate change, traffic congestion, or antibiotic resistance, for which there is no market. Indeed, from a market failure perspective, most societal challenges are seen as negative externalities, a source of market failure that works at the system level, which would justify SIBs' challenge-led (or systemic) role. The socio-economic system as a whole results in "costly" outcomes that are undesirable from a societal point of view. Negative externalities are not reflected in the price system: there is no "equilibrium" price because there is no market (violation of FFT's first condition). For instance, climate change can be seen as a negative externality from carbon-intensive production methods or the burning of fossil fuels. Indeed, the Stern Review on the economics of climate change (Stern, 2006) stated, "Climate change presents a unique challenge for economics: it is the greatest example of market failure we have ever seen" (Stern, 2006, p. 1). SIBs' mission-oriented investments would seek to internalize such external costs by promoting the development of new technologies and innovations that represent a "solution" to a given societal challenge. The challenge-led role can be also 
associated with market failures due to information asymmetries, as in the case where private agents lack the information about savings potential of energy efficiency investments. The kind of service-side measures provided by SIBs (as the example of KfW's advice service) also helps to coordinate expectations by signalling governmental support and commitment to addressing a particular challenge.

\section{THE MFT EVALUATION TOOLBOX AND ASSOCIATED CRITICISMS}

\subsection{The MFT Evaluation Toolbox}

Each of the four roles of SIBs is justified through MFT as a mean of addressing a particular type or source of market failure. Thus, MFT calls for a limited role for SIBs, the activities of which should be restricted to very specific areas (that is, those that suffer from market failures) to fill in the gaps left open by private initiative (Gutierrez et al., 2011). This should be done in a way that minimizes the risk of government failure, from crowding out to cronyism and corruption. MFT assumes that once the sources of the failure have been addressed, market forces will efficiently direct the economy to Pareto equilibrium. From then on, it is expected that market forces left alone will provide economic growth and development.

To minimize the risks of government failure, MFT calls for an institutional structure that insulates the public sector from the private sector (to avoid issues such as agency capture). In this view, the role of the state is limited in time, size and scope: it is simply to correct market failures and perform a subsidiary role to private initiative, so that once sources of market failures were addressed, it would be sufficient to have little more than a "minimal" state that performs only "unanimously approved" functions, such as guaranteeing property rights and enforcing contracts (Atkinson \& Stiglitz, 1980). In other words, the size of the state apparatus could decrease, which would reduce the roles and importance of SIBs over time.

In MFT, these normative rationales are accompanied by a toolbox for public investment decision-making, implementation, and evaluation. The market failure framework has developed concrete indicators and methods to evaluate public investments, which stem directly from the theory itself, usually through a cost-benefit analysis that estimates whether the benefits of public intervention compensate for the costs associated, both with the market failure and the implementation of the policy (including government failures). The mainstream diagnostics and evaluation approach (based on market failure theory) involves identifying the sources of the 
market failure and targeting policy interventions on their correction. It mostly entails ex-ante considerations about administrative and fiscal requirements and the political-economic consequences of the intervention (Rodrik, 2004). Such an exercise usually consists of the following steps:

- An ex-ante cost-benefit analysis that weighs up the costs of the failure, the (private and social) benefits from addressing it, and the costs and risks of government failure.

- An ex-ante identification of sources of market failures and of "second-best" policy tools to address these failures.

- An ex-ante diagnostic of the best principal-agent structure that avoids governmental capture by private interests (insulation/autonomy) and that forces private agents to do what the principal (government) wants.

- An ex-post evaluation of the outcomes of the intervention vis-à-vis the ex-ante quantifiable prediction of the likely outcomes of the intervention.

This is a limited toolbox for evaluating public investments, because doing so represents a static exercise of evaluation of an intrinsically dynamic process. Therefore, as we argue in section 5 , there is a mismatch between the intrinsically dynamic character of economic development and the static tools with which the role of the state in the process is evaluated. Indeed, scholars working within the systems of innovation perspective have argued that "market failure is too narrow a perspective to provide an adequate analytical or empirical basis for innovation policy" and that justifying public support for science, technology and innovation "on the basis of purported 'market failures' is misleading and leads policy to focus on a limited set of levers aimed at mimicking optimal market outcomes by making marginal adjustments through tinkering with taxes and subsidies" (Dodgson et al., 2011, p. 1146). This systems of innovation critique of MFT has resulted in the development of alternative frameworks based on the notion of "system failures" (Dodgson et al. 2011; Aghion et al., 2009; Gustaffson and Autio, 2011; Weber and Rohracher, 2012; Bleda and Del Río, 2013). Our discussion in section 5 is an attempt to move beyond the "failure' rationale"-be it MFT or the system failures approach, both of which resulted in policy recommendations that limit the role of the state in the economy to "fixing failures." We argue, instead, that SIBs do more than fix failures: they shape and create markets, by targeting financial resources and service-side measures to particular technologies, 
firms, and sectors within an overarching goal or mission. Before we present our alternative justification of the role of SIBs, we shall discuss the standard criticisms to SIBs: issues of "government failure."

\subsection{MFT-related Criticisms to State Investment Banks}

MFT provides a normative rationale for and precise tools to evaluate the roles of state investment banks. In practice, however, the consensus regarding the importance of SIBs has changed substantively over time, "from a clear case for the need for DBs in the 1950s to the view that DBs created more inefficiencies and distortions to a more eclectic view of market friendly interventions within a general limited role for the institutions" (Gutierrez et al., 2011, p. 6). Accordingly, some economists and economic commentators have criticized the enhanced roles that SIBs have been playing in the economy, suggesting that their actions often lead to outcomes that are worse than the issues they seek to address. Criticisms of SIBs stem directly from the market failure perspective and can be categorized into four broad types (criticisms are often directed to public investments in general, of which investments by SIBs is a particular type):

\section{a. $\quad$ Financial Repression and Crowding Out}

One of the most widespread criticisms of the activities of SIBs is that their investments crowd out private investments. For instance, in a recent article about the level of investments carried out by the Brazilian development bank BNDES, the Financial Times wrote that

[c]ritics have long pointed to the BNDES as a big impediment to the formation of mature capital markets in Brazil. About three quarters of all corporate loans lasting three years or more come from the BNDES. What chance is there of developing a functioning market based on the needs of the other quarter that can't get BNDES funding? (Wheatley, 2013: online).

In other words, by displacing (crowding out) private initiative, BNDES's investments would prevent the development of a long-term capital market instead of being a solution to its absence. Another example of the criticism is the fear that KfW's dominance of the German long-term capital market, commercial bank margins for long-term infrastructure and industry projects in Germany are not sustainable, which therefore prevents the full development of the market (Mussler, 2013). In academic terms, this criticism is conceptualized through the financial 
repression hypothesis (McKinnon, 1973), according to which the use (by development banks or other central planning institutions) of low or negative (in real terms) long-term interest rates is the cause, not the consequence, of the inexistence of a long-term credit market. Managed longterm interest rates would crowd out credit that would otherwise be supplied by private agents in a free market, thereby inhibiting both the activity of commercial banks and the creation of a capital market.

Theoretically, crowding out criticisms are associated with some mainstream (NeoKeynesian or New Classical) growth models that result in public investments crowding out private investments, particularly if governmental deficits are financed through debt (Friedman, 1979; Hemming et al., 2002). Based on the results from these models, academic critics argue that development banks may crowd out private investments through a direct and/or an indirect route. The former occurs when public investment substitute for private investments, that is, they subsidize or directly fund investments that offered a large enough return on investment to motivate financing by profit-seeking firms (Cohen and Noll, 1991, apud David et al., 2000); the latter occurring when public investments induce changes in interest rates and exchange rates, which lead to lower private investments. There have been numerous scholarly attempts to test the crowding out hypothesis, and they have reached contradictory conclusions (for reviews, see Hemming et al., 2002; Hur et al., 2010; for a review of studies that investigated whether public R\&D crowds out private R\&D, see David et al., 2000). Because the crowding out hypothesis is derived from specific economic models, its validity remains controversial (Tassey, 2012). Thus, a demonstration of the direction of causality between public investments and the inexistence of a long-term capital market or confirming the crowding out hypothesis has proved elusive. ${ }^{23}$

\section{b. Misallocation of Resources Due to Political Biases}

Krueger (1990) argued that, historically, "government investment programs were highly inefficient and wasteful... [and] led to high rates of inflation, with their attendant consequences for resource allocation, savings [behaviour], and the allocation of private investment" (p. 3). She

\footnotetext{
${ }^{23}$ The seminal study by Aschauer (1989) has shown, however, two opposing effects of public investments (in general, not by SIBs) over private investments: an ex-ante reduction in private investments directly proportional (one-to-one) to the increase in public investments; and a complementarity between public investments in infrastructure and private investments, with an accompanying long-term increase in the profitability of private capital stocks. The author concludes that the net effect of an increase in public investments "is likely to raise private investment." (p. 186).
} 
also claims that misallocation of resources by the public sector is often accompanied by "largescale and visible corruption" and benefits the most affluent members of society. In short, the criticism of misallocation of resources due to political biases states that public ownership politicizes resource allocation and reduces the efficiency of SIBs. In the case of public investments in R\&D and innovation, Cohen and Noll (1991) argue that most public investment programs are, in fact, instances of "pork-barrel politics." They are created to reward regional constituencies and particular interest groups or to secure passage of other, unrelated, legislative proposals ("logrolling"), being susceptible to performance under-runs and cost overruns (see also discussion in Etzkowitz and Leydesdorf, 2000). ${ }^{24}$

In line with this view, critics argue that due to political interference, SIBs would tend to finance government-sponsored projects without giving proper consideration to the objective of optimal resource allocation; instead, the goal would be to leverage an otherwise constrained government budget (Gutierrez et al., 2011). In most cases, the criticism goes, governmentsponsored projects are those that are highly visible (big projects) or those that favor their allies/constituencies (pork-barrel politics), and often well-connected incumbents that want to expand their businesses (La Porta et al., 2002; Hanson, 2004). The flip-side of the argument is that politicians will be reluctant to "let a project fail" due to the political consequences of such a failure. Ultimately, if the portfolios of (government-sponsored) projects do not provide enough cash flow, the SIB will become insolvent and even face bankruptcy (Gutierrez et al., 2011). ${ }^{25}$ Such criticisms may lead to other practical consequences. For example, BNDES, which is often the target of criticism due to its size relative to the Brazilian economy and to its active policy of supporting large national companies (“champions”), was downgraded by Moody’s Investors Service in 2013, due to "concerns that they had become too heavily exposed to their biggest borrowers" (Leahy, 2013: online), because this would risk BNDES's solvency if these

\footnotetext{
${ }^{24}$ Therefore, in many cases, public R\&D and innovation projects would be attempts to solve interest group conflicts, and Arrow's "Impossibility Theorem" (that is, the fact that pluralistic democracies cannot have a voting structure that meets specific fairness criteria such as Pareto efficiency, because voting preferences are not wellbehaved and consistent amongst alternative candidates). Cohen and Noll (1991) confirm this hypothesis in six case studies of government funding for near-commercial stage projects (in aerospace and energy). We thank one anonymous reviewer (from the SPRU working paper series) for calling our attention to the nuanced argument of misallocation of resources due to political biases (and for the reference).

${ }^{25}$ Hanson (2004) cited examples from public banks in Indonesia and India. Krueger (1990) cited examples from Thailand and Sri Lanka.
} 
"champions" prove themselves to be losers. This specific criticism also relates to the next type of government failure.

\section{c. Incapacity to "Pick Winners"}

Many SIBs target their finance at particular technologies and sectors, in an attempt to pick winners. However, critics argue, SIBs (and governmental agencies, in general) are poor at doing this because they lack the necessary capability, information, and incentives to succeed in these attempts (Hanson, 2004). This view argues that politicians and bureaucrats are bad or biased managers and lack the discipline provided by markets. Therefore, governmental attempts to pick winners "ignore both government's deficiencies in forecasting industrial change and managing entrepreneurial activity, and the lessons from past experience" (Grant, 1982, p. 29). While governments could be in a better position than private business to forecast technical change, their selection of "winners" would necessarily reflect a consensus instead of a variety of views (as when markets select technologies); this, in turn, would result in the selection of a suboptimal technology (Grant, 1982). This view is shared even amongst some Schumpeterian economists, who argue that governments' poor record in identifying successful technologies in advance means that "public support for innovating SMEs should not take the form of direct grants. Nor should it take the form of government debt or direct equity financing" (Martin and Scott, 2000, p. 440; see also the report by Nelson and Langlois (1983), who argue that most picking-winner policies fail). This criticism was summarized in an article in The Economist, titled "Picking Winners, Saving Losers," which concluded: "The present round of industrial policy will no doubt produce some modest successes — and a crop of whopping failures" (The Economist, 5 August 2010, online). In the case of SIBs, critics also argue that in public financial institutions, political considerations substitute for commercial considerations (Hanson, 2004). Thus, due to a supposed technical and political incapacity, Lisboa and Latif (2013) criticized BNDES, which "has been picking up 'winners' that neither invests $[s i c]$ in capital-intensive projects nor in projects that improve their performance" (p. 38). Similarly, through an in-depth analysis of BNDES investments, Lazzarini et al. (2015, p. 250) argue that

BNDES is lending to firms that are not changing their performance and investment conditional on the new loans... By targeting those firms, development banks may be cherry picking borrowers, leaving mostly high-risk firms to private lenders, hence inhibiting the emergence of a private market for long-term lending (ibid.). 
In this sense, BNDES would not be picking winners, while at the same time crowding out private investments. A flip-side of this criticism is particularly directed to countercyclical investments that aim to "'ail out losers"; in the 1980s, for instance, BNDES was criticized for being a "hospital of companies" due to its investments (even acquisition) of firms in bankruptcy (Pinheiro, 2000). During the latest financial crisis, KfW was also criticized for its "expensive and repeated efforts" to save the IKB Deutsche Industriebank, which had lost billions in mortgage-backed securities; after the crisis KfW sold its 90.8-percent stake in IKB for a substantial loss (estimated at more than $€ 7$ billion) (Wilson and Bryant, 2008). The problem with such investments is that they would distort market mechanisms (whereby "bad" companies are selected out) and even lead to issues of oral hazard.

\section{d. Inefficient Governmental Structures}

Critics argue that SIBs should be structured in a way that balances the need to hold managers accountable for their decisions against the risk of capture by private interests (Gutierrez et al., 2011). Therefore, the optimal principal-agent structure (governance) for an SIB would facilitate the setting up of incentives for managers to meet the different objectives defined by the state (for example, supporting the development of industry, creating employment, providing finance to SMEs, promoting innovation, addressing societal challenges, etc.) and allow the state to judge SIB performance and hold management accountable (Hanson, 2004). It would also insulate management from influence by other (private sector) stakeholders engaged in rent-seeking (Krueger, 1974), who would be willing to use political pressure and even bribery to obtain a subsidized loan from the state development bank. Critics argue that, in practice, SIBs (or public banks in general) "tend to lack good information systems, because of widespread operations, weak national communications, and the lack of information technology personnel as well as funds to hire them, let alone buy equipment" (Hanson, 2004, p. 10). This results in a nontransparent bureaucratic structure that is prone to inefficiency and political capture. Lisboa and Latif (2013), for instance, accused Brazil's BNDES of not complying "with the key design attributes for a successful industrial policy ... There is no transparency on BNDES operations. No available data on total subsidies provided, benefited companies or sectors and the costbenefit of policies. Furthermore, the evaluation of the outcome of BNDES investment decisions is also unavailable" (p. 38). On its turn, KfW's risk management has been criticized for being unable to detect and prevent the transfer of $€ 300$ million to Lehman Brothers when this bank 
was already insolvent (the automated wired transfer happened on the same day Lehman filed for Chapter 11, 15/9/2008) (Wilson and Bryant, 2008).

\section{TOWARD A NEW FRAMEWORK: THE ROLES OF SIBS FROM HETERODOX ECONOMICS PERSPECTIVES}

In this section, we will show the limitations of the market failure justification in explaining the increased role of these banks and propose an alternative framework based on notions from heterodox perspectives, which have either provided a critique of market failure theory, or produced concrete insights on the roles of state investment banks, and yet they have achieved little systematic impact in the way state action is justified, formulated, implemented, and evaluated. The key theories and concepts that we draw on include Keynes' notion of "socialisation of investment"; Minsky's stage view of capitalism (his concept of "money manager capitalism") and proposal for community development banks; Schumpeter's conceptualisation of economic development as a dynamic process; Polanyi's view of markets as shaped and created by the state; Neo-Schumpeterian studies on microeconomic dynamics and the concepts of technological trajectories and techno-economic paradigm shifts in evolutionary economics (Dosi, 1982; Perez, 2002); mission-oriented policies in science and technology policy research (Mowery, 2010; Foray et al., 2012); developmental network state in development economics (Wade, 1990; Amsden, 2001; O’Riain, 2004; Block \& Keller, 2011); and Mazzucato's (2013a) “entrepreneurial state.” By combining concepts from these theories, we aim to develop a qualitatively different typology that represents the seeds for a new theoretical framework of what SIBs do.

\subsection{Countercyclical Role}

Recent cycles of boom-and-bust have been exacerbated by dysfunctional financial markets that focus on speculative gains even during periods of bust. Thus, the issue is not so much that private agents are risk averse and preferences are pro-cyclical (as in MFT), but that they have become increasingly speculative over the past decades. The post-Keynesian literature has showed that the type of financial structures in an economy (for example, the quantity and type of banks) is not inconsequential to the workings of the real economy and productive enterprises. Some structures are conducive to what Minsky calls the "capital development" of the economy 
(see also next section), which includes privately owned capital equipment, technologies, skills, and public infrastructure (Minsky, 1992). However, capital development is hampered when speculative finance targets low-risk, short-term gains through the trade of securities and other investments types that "[amount] to little more than pyramid schemes" (Wray, 2012, p. 310). Minsky described the laissez-faire financial architecture that was established in the 1980s as "money manager capitalism," which he believed was inhibiting the "capital development of the economy," because it led to speculation, short-termism, volatility, uncertainty, and financial instability (Minsky and Whalen, 1996; Papadimitriou and Wray, 1998). So, the problem is not so much one of risk aversion, but of financialization and speculation, which affect the countercyclical role, as well as the other three roles of SIBs.

This situation, which has repeated itself in capitalist history (Perez, 2002), does call for public policy intervention, which may take the form of a reform of the financial system and/or of innovation and fiscal policies (for example, through SIBs) — both of which were policies implemented in the United States with the New Deal, which has been influenced by the ideas of Keynes. In the realm of fiscal policy, Keynes called for "socialisation of investments" as "the only means of securing an approximation to full employment” (Keynes, 2006 [1936], p. 246). However, Keynes was not so much concerned with underinvestment as he was with underutilization of productive resources, particularly labor. The goal of his policy proposals was not to increase investments per se but to decrease unemployment. As Pavlina Tcherneva notes:

Public investment is a direct approach to reducing unemployment. Add to that the secondary employment effects produced by the multiplier effect and we can estimate how much public-works spending is needed to close the [labour] demand gap. Whenever Keynes spoke of how much national income and expenditure are needed to maintain full employment, his "calculations are in terms of equivalent men... and women, if they are unemployed... (Keynes, 1980, p. 298)” (Tcherneva, 2008, p. 18).

In this sense, "bailing out of losers" could be justified, if the goal is to maintain jobs, for example.

In summary, while the need for public promotion of countercyclical credit is usually seen as resulting from coordination failures, SIBs actually do much more than just correct markets in this role. SIBs play an important short-term role of directing finance to productive opportunities, and in this sense, the countercyclical role provides the basis for all other SIB roles, laying the groundwork for the capital development of the economy, the full utilization of 
labor resources, the creation of new technologies and sectors, and the direction of technoeconomic change through challenge-led/mission-oriented investments.

\subsection{Capital Development (or Developmental) Role}

In Schumpeter (1934 [1912]), economic development is a discontinuous endogenous process, and results from investments in "new combinations": new methods of production, new products, opening of new markets, new sources of supply, and new forms of organization - all of which disturb the prevailing economic equilibrium. From the entrepreneur or the corporation point of view, the objective of introducing new combinations is the creation of "monopoly rents" (or "Schumpeterian rents"). Interventions and investments that seek to address a market failure aim to bring the economy back to equilibrium of perfect competition, thereby "killing" Schumpeterian rents. This is at odds with Schumpeter's view of economic development. In fact, in the "lost" seventh chapter of Theory of Economic Development, Schumpeter points to the limitation of the static perspective of mainstream economics that sees development as an exogenous process:

Our most important result is that such economic development really exists. [...] This conception is the contrary of an alternative explanation which can be expressed as follows: an economic equilibrium, once attained, will be maintained, as long as there is no disturbance coming from the outside. [...] According to this conception the purely economic plays only a passive role in development. Pure economic laws describe a particular [behaviour] of economic agents, whose goal is to reach a static equilibrium and to re-establish such a state after each disturbance. [...] It is true that this way of thinking corresponds to the fundamental principles of static economics. It allows for the precise formulation of static laws... Yet we maintain that the conception described is not sufficient to explain the real development of the economy (Schumpeter, 2002 [1912], p. 96-97).

The limitation of the market failure view on the developmental role becomes more apparent when we look at the work of developmental economists studying catching-up and industrialization processes (e.g. Prebisch, 1950; Singer, 1950; Hirschman, 1958; Nurkse, 1966). It was Moses Abramovitz (1986), an economist more concerned with growth, productivity and business cycles in developed economies, who originally formulated the "catch-up hypothesis": "Countries that are technologically backward have the potential for generating growth more rapidly than that of more advanced countries, provided their social capabilities are sufficiently developed to permit successful exploitation of technologies already employed by the 
technological leaders" (p. 390, emphasis added). Key in this definition is the "social capabilities" qualification, a variable that is difficult to measure but includes technical competence and political, commercial, industrial, and financial institutions (Abramovitz, 1986). In fact, Prebisch (1950), Singer (1950), Nurkse (1966), among others, had theorized about problems of (lack) industrialization, terms of trade imbalances, and insufficient availability of capital in underdeveloped countries, providing the foundation of active development strategies through governmental investments and policies (this view also justifies the support for exporting activities, which would help to diversify a country's productive base and address these issues). From this perspective, economic development is not the result of natural (exogenous and exante) competitive advantages, but of the endogenous creation of new opportunities that lead to the establishment of competitive advantages (Rodrik, 2004).

Work on the developmental state has revealed the importance of the "visible hand" of the state in industrialization and technological change (Wade, 1990; Amsden, 2001; Chang, 2002). More recently, this literature has also emphasized the developmental network state as being key: a decentralized network of different types of state agencies that can foster innovation and development. This requires the cost structure of an economy to be discovered in order to identify which types of goods and services that already exist in world markets can be produced in a domestic economy at low cost (Rodrik, 2004). In line with this alternative view, SIBs play a central role in developing social capabilities, promoting capital accumulation, supporting the catch-up process, and fostering technical change; in many instances, they also represent a "lead agency," coordinating a network of actors in latecomer countries' development efforts (Mathews, 2006). In order to do this, a development bank/SIB may work as an agency to nurture knowledge development; invest in infrastructure; promote strategic trade (such as import substitution, securing sources of materials) and financial leverage; prioritize investments in existing strategic sectors (reinforcing comparative advantages); create "national champions" that are able to compete in international markets; and provide coherence to economic policies (Reinert 1999; Mathews, 2006; Etzkowitz and Ranga, 2009).

While the need for some of these activities may be explained by market failure theory (for example, investment in public goods like knowledge and infrastructure), in fulfilling this developmental role, SIBs do much more than just provide financial capital to fix failures. 
Because economic development is an endogenous process, they provide social capital ${ }^{26}$ for the development of social capabilities, coordinate initiatives and public-private partnerships, foster synergies, and promote the introduction of new combinations that create Schumpeterian rents. In this sense, the developmental role of SIBs also underlies (and overlaps with) the roles of supporting new ventures and promoting challenge-led investments, both of which also require provision of social capital and, in the case of challenge-led investments, the development of shared visions (e.g., via industrial plans).

\subsection{New Venture Support Role}

There are two key reasons why a focus on smallness, as implied by the market failure perspective on the new venture support role (small firms would be risky and lack guarantees to secure external funding), is misguided. First, Minsky suggested that one form that the Keynesian socialization of investments should take is of community development banks, which were established to fill the gap in banking and financial services for small firms and individuals in certain local communities (Minsky, 1993). The ethos of community development banks was to promote the financial inclusion of certain strata of the society and certain regions, but this is not an end in itself, as would appear from a market failure perspective. Minsky was concerned with the capital development of the economy, which he conceived as the development of human capital and social capital. Therefore, the goals of community development banks that would execute the microeconomic role of SIBs are dynamic: the inclusion and development of individuals, firms, and communities otherwise excluded from the economic system. Incidentally, this is often achieved through the provision of venture capital to small firms or microfinance to individuals.

Second, not all SMEs face a problem of capital supply due to adverse selection and moral hazard concerns. It is a myth that all SMEs are equal in terms of their propensity to innovate and grow (Mazzucato, 2013a). There is no systematic evidence of a uniform relationship between firm size and growth (Haltiwanger et al., 2013). Furthermore, small firms appear as less productive than larger ones, due to management issues (Bloom and Van Reenen,

\footnotetext{
${ }^{26}$ Lall (2002, p. 103) defined social capital as "the ability of individuals in a group to form relationships of trust, cooperation and common purpose." The state may promote social capital by bringing together different stakeholders of the capital development process and coordinating them through the establishment of a shared industrial strategy plan, which are often funded by SIBs (see section 3.2).
} 
2007). The challenge for SIBs is not so much to provide abundant finance for all SMEs, but to find and nurture the so-called "gazelles" (Nightingale and Coad, 2014); that is, young, high-tech firms that are SMEs. Nurturing this group requires as much financial capital (in the form of VC) as social capital (sometimes networking and co-management). Identifying the economic gazelles is akin to what Rodrik (2004) called the process of "discovering" an economy's cost structure and activities that can be profitably exploited to promote growth. Therefore, the microeconomic development role is also a type of industrial policy, as it complements the macroeconomic development role by selecting specific firms and projects that have the potential to generate Schumpeterian rents and economic development.

Moreover, economists working in the Schumpeterian tradition further theorized about technology development and innovation ("new combinations") as an endogenous process to economic growth and development. Therefore, the issue is not one of "information asymmetries," which assumes that some parts know the risks of an innovation project succeeding or failing. Innovation is a venture that is not only risky, but fundamentally uncertain, so no one knows the odds of success. Innovation requires financial capital, but the type of financial capital received affects the types of investments made (O'Sullivan, 2004; Mazzucato, 2013b). In fact, innovation requires patient, long-term, committed financial capital (funding, in the Keynesian conceptualization). But from a market failure perspective, any kind of financial capital and even tax breaks would support high-tech SMEs and innovation development. The mutual causation between types of financial capital and investments is a key reason why SIBs have been increasingly mobilized to provide long-term committed venture capital for high-tech start-ups; that is, firms (usually small) that develop radical innovation projects. In this sense, the new venture support role also provides a basis for SIBs' challenge-led investments that seek to promote radical innovations that address societal challenges.

SIBs" "new venture support role" is akin to the actions of an entrepreneurial state. This concept, introduced by Mazzucato (2013a), builds on the notion of the "developmental state," but pushes it further by focusing on the type of risk that the public sector has been willing to absorb and take on. Mazzucato (2013a) describes the risk-taking role the state has played in the few countries that have achieved innovation-led growth, and shows that, in those countries, the state played a lead investment role across the entire innovation chain, from basic research to early-stage seed financing of companies to finance for commercialization and market entry. This added focus on the type of risks taken by the state led Mazzucato (2013a) to conclude that 
ignoring the high-risk and uncertainty that the state has absorbed has caused the fruits of innovation-led growth to be privatized, even though the underlying risk was socialized (that is, funded through tax-payers money). It is usually assumed that the returns to the state will occur through higher tax income. However, given that this return-generating system is broken, more thinking is needed on concrete ways in which direct mechanisms can be generated for the state to create a "revolving fund," so that inevitable losses (caused by the uncertain nature of innovation) can be covered, and the next round funded-as is the case with private venture capital. State investment banks provide a concrete mechanism through which "socialisation of rewards" can be achieved. This is because, in many of their new venture support investments, they retain equity, so that if these venture investments are successful, they may result in windfall gains. Moreover, even for its less risky investments, the use of loans (instead of grants, subsidies or tax breaks) provides another mechanism through which SIBs are rewarded.

\subsection{Challenge-led Role}

From the market failure perspective, societal challenges are negative externalities that impose a cost to society that, by definition, is not reflected in prices. However, such a view is limited in its ability to explain what SIBs do to address societal challenges. Science and technology policy research on mission-oriented initiatives (see below) provides an alternative and more complete conceptualization of SIBs' systemic role because, in performing it, they go beyond addressing a market failure in order to internalise external costs. In this role, SIBs help to "make things happen that otherwise would not," as Keynes called for the state to do (Keynes, 1926). More importantly, they pave the way for a "Great Transformation," as described by Polanyi (2001 [1944]), who showed that capitalists markets are deeply "embedded" in social and political institutions, rendering meaningless the usual static state vs. market juxtaposition. In their challenge-led role, SIBs are not simply fixing failures from markets; they are shaping and creating new technologies, firms and sectors, and, ultimately, markets - all of which will help to address a societal challenge.

A new great transformation, required to address the big contemporary challenges, will not arise from market forces, because markets are "blind," and even if they do not fail in a Pareto sense, they are incapable of providing a new, qualitatively different direction to economic development. The concepts of technological paradigms and technological trajectories (Dosi, 1982; Nelson and Winter, 1982) reveal the limitation of market forces in providing a 
direction to economic development. A technological paradigm has a threefold definition (Dosi, 1982, p. 148): it is an outlook of the relevant productive problems confronted by firms (as producers of technologies or innovators); it represents a set of procedures (routines) of how these problems shall be approached; and it defines the relevant problems and associated knowledge necessary for their solution. A technological trajectory, in turn, represents the direction of progress within a technological paradigm. Therefore, technology development is a problem-solving activity, and a technological paradigm "embodies strong prescriptions on the directions of technical change" (ibid., p. 152). This is why market signals are limited in terms of providing direction to techno-economic development; they only work within the parameters of the paradigm, and therefore influence the rate of change more than its direction. When two or more technological paradigms compete, markets may influence which one is selected (the one which minimizes costs). Once established, however, paradigms have a powerful "exclusion effect," whereby some technological possibilities are discarded because they are incompatible with the prevailing paradigm and are therefore "invisible" to agents. Thus, a techno-economic system of innovation may be locked into a self-reinforcing, path-dependent trajectory (Dosi and Nelson, 1994). This becomes a problem if the trajectory being followed (or the paradigm itself) is inferior or suboptimal to what could be achieved with technologies that transgress the paradigm (or with a different paradigm).

Perez (2002) expanded the notion of technological paradigm to techno-economic paradigm in order to account for the non-technological forces (economic and social institutions) that characterize certain periods of capitalist history and affect both the economic and social systems. Her theory of "techno-economic paradigm shifts" is a historical perspective on the long waves of development that accompany technological revolutions. When a new technological revolution emerges, the socioeconomic system remains stuck within the bounds of the previous (socio) techno-economic paradigm, which means that market forces are incapable of directing the system toward a new one; consequently, the modernizing and rejuvenating potential of the new revolution is stifled. In other words, there are mismatches between elements of the socialtechno-, and economic systems (for example, social expectations, R\&D routines, tax regimes, labor regulations, etc.). In order to overcome these mismatches, it is necessary to build new institutions that favor the diffusion of the new paradigm. In all previous technological revolutions, governments have led the process of institution building that allowed new technoeconomic paradigms to replace the old ones. Perez (2002) specifically pointed to the role of 
public policy in allowing the full deployment of technological revolutions, such as the effect of suburbanization on the ability of the mass production revolution to diffuse throughout the economy. Due to their experience and superior position in the economy, SIBs represent a concrete tool through which public policy can promote great transformations. In fact, this has happened in the $19^{\text {th }}$ century, when industrial banks - the predecessors of modern SIBs - played a key role in providing the finance for the construction of the continental European railway network (De Aghion, 1999). This network totally transformed the socioeconomic landscape to the point that Perez (2002) called the third technological revolution "the age of railroads."

The stream of research on technological and techno-economic paradigms highlights the importance of cognition - rather than of "preferences" and "expectations," as in market failure theory - when establishing the direction of technological change. Paradigms are powerful, enabling and constraining institutions that favor certain directions of techno-economic development and obstruct others. In order to coordinate techno-economic development toward a new, qualitatively different route, we need a paradigm shift that will avoid the constant renewal of prevailing trajectories, which happens if market forces provide directionality to the system. From this perspective, the challenge-led role of SIBs concerns the creation of a new vision that will coordinate cognitive efforts of different (public and private) agents and direct their action to areas beyond the existing paradigm. It therefore complements the developmental role and the provision of social capital, which operates in long time frames, in that the vision (or what we will call 'visionary capital') provided by the challenge-led role is a mechanism to coordinate actions and expectations in the short-run.

Historically, innovation policies have created such a vision through the establishment of "missions" that gave a direction to techno-economic change. Previous mission-oriented policies were those driven by military or national security motives (such as those behind the origin of DARPA in the US Department of Defense or NASA) and aimed to achieve clearly defined technical goals (creating a network of connected computers or putting a man on the moon). In recent years, there have been calls for a return to such policies to address "grand societal challenges" (see Mowery et. al, 2010). However, Foray et al. (2012) contrasted missions of the past, with such contemporary missions as tackling climate change. While missions of the past aimed to develop a particular technology (with the achievement of the technological objective signalling that the mission was accomplished), contemporary missions have addressed broader and more persistent challenges, which require long-term commitments to the development of 
technological solutions. Thus, mission-oriented motivations have more recently been used to set up dynamic public agencies in other non-military areas such as energy security (ARPA-E) and health (National Institutes of Health, NIH). By building on their accumulated capability and expertise in fulfilling the other three roles, SIBs seem well positioned to play a central role in the execution of new mission-oriented policies. Therefore, analysis of how SIBs fulfill their challenge-led (or mission-oriented) role represents a new and important research agenda, given the pressing need to carry out investments that promote smart, inclusive and sustainable growth and tackle societal challenges.

\section{DISCUSSION}

\subsection{Summary: Mainstream vs. Heterodox Conceptualisations of the Roles of State Investment Banks}

Table 3 summarizes our discussion in the previous sections into a synthetic typological framework, which, we argue, provides the seeds for the development of a new theoretical framework. Row 1 summarizes our discussion of how market failure theory justifies what SIBs do and should do. Rows 2, 3, and 4 of the table summarize our discussions of the limitations of MFT and of alternative conceptualizations provided by heterodox theories. Row 5 presents the usual criticism attached to SIBs (see further discussion in subsection 6.2.1.). Rows 6 and 7 hypothesize about the risks and uncertainties involved in each role and the potential of each role to generate "windfall gains" (see further discussion in subsection 6.2.2.).

Note that this framework table is an "ideal type"; what SIBs actually do in reality often overlaps, as the evidence documented in section 2 has shown. Furthermore, as we made explicit in our discussion in section 5, and indicated in rows 4-7, each role builds on or overlaps with the previous one, so that, for example, the challenge-led role requires the provision of visionary, venture, social, and financial capital (and long-term funding). As such, aspects theorized by one author are relevant for more than one role. However, based on our discussion of MFT and heterodox theories, we claim that these four roles are conceptually different. 
Table 3 Analytical Framework: Characteristics of Different Functions of State Investment Banks

\begin{tabular}{|c|c|c|c|c|}
\hline & $\begin{array}{l}\text { Countercyclical } \\
\text { role }\end{array}$ & Developmental role & $\begin{array}{l}\text { New venture support } \\
\text { role }\end{array}$ & Challenge-led role \\
\hline $\begin{array}{l}\text { Market } \\
\text { failures }\end{array}$ & $\begin{array}{l}\text { Coordination } \\
\text { failures }\end{array}$ & $\begin{array}{l}\text { Public goods, } \\
\text { network externalities }\end{array}$ & $\begin{array}{l}\text { Information asymmetries, } \\
\text { adverse selection }\end{array}$ & Negative externalities \\
\hline $\begin{array}{l}\text { Market } \\
\text { failure } \\
\text { limitation }\end{array}$ & $\begin{array}{l}\text { Not just } \\
\text { underinvestment } \\
\text { and risk-aversion: } \\
\text { underutilisation of } \\
\text { labour and } \\
\text { financialisation }\end{array}$ & \begin{tabular}{|l|} 
Not just \\
infrastructure and \\
knowledge: \\
Schumpeterian rents, \\
capital development \\
and social \\
capabilities \\
\end{tabular} & $\begin{array}{l}\text { Not just SMEs and tax } \\
\text { breaks: community } \\
\text { development banks in } \\
\text { support of gazelles and } \\
\text { R\&D/innovation } \\
\text { development; discovery } \\
\text { process }\end{array}$ & $\begin{array}{l}\text { Not just internalising } \\
\text { costs: Making things } \\
\text { happen, great } \\
\text { transformations; } \\
\text { blindness of markets }\end{array}$ \\
\hline Beyond & $\begin{array}{l}\text { Smoothing the } \\
\text { business cycle: } \\
\text { employment, } \\
\text { multiplier effect, } \\
\text { socialisation of } \\
\text { investments }\end{array}$ & $\begin{array}{l}\text { Economic planning, } \\
\text { strategic trade, } \\
\text { national champions, } \\
\text { social inclusion, } \\
\text { structural and } \\
\text { technical change, } \\
\text { regional } \\
\text { development, }\end{array}$ & $\begin{array}{l}\text { Entrepreneurship, } \\
\text { technical innovation }\end{array}$ & $\begin{array}{l}\text { Addressing societal } \\
\text { challenges; creating } \\
\text { visions through } \\
\text { missions; shaping and } \\
\text { creating markets }\end{array}$ \\
\hline \multirow{4}{*}{$\begin{array}{l}\text { Type of } \\
\text { capital }\end{array}$} & \multicolumn{4}{|c|}{ Financial capital (finance, liquidity) } \\
\hline & & \multicolumn{3}{|l|}{ Social capital } \\
\hline & & & \multicolumn{2}{|l|}{ Venture capital } \\
\hline & & & & "Visionary capital" \\
\hline \multirow[t]{4}{*}{ Criticism } & \multicolumn{4}{|c|}{ Moral hazard (bailing out losers) } \\
\hline & & \multicolumn{3}{|c|}{$\begin{array}{l}\text { Crowding out and misallocation of resources (rent-seeking, pork barrel } \\
\text { etc.) }\end{array}$} \\
\hline & \multicolumn{4}{|c|}{\begin{tabular}{|l|l} 
& Incapacity to 'pick winners' \\
\end{tabular}} \\
\hline & & & & Inefficient structures \\
\hline \multirow{4}{*}{$\begin{array}{l}\text { Risk \& } \\
\text { Uncertainty }\end{array}$} & \multicolumn{4}{|c|}{ Lowest (some risk, very low uncertainty) } \\
\hline & \multicolumn{4}{|c|}{ Lower (some risk, higher uncertainty) } \\
\hline & \multicolumn{4}{|c|}{ Higher (high risk, high uncertainty) } \\
\hline & & & & $\begin{array}{l}\text { Highest (high risk, } \\
\text { very high uncertainty) }\end{array}$ \\
\hline \multirow{4}{*}{$\begin{array}{l}\text { Potential for } \\
\text { windfall } \\
\text { gains }\end{array}$} & \multicolumn{4}{|c|}{ Lowest (some potential of buying undervalued assets) } \\
\hline & \multicolumn{4}{|c|}{ Lower (returns via crowding in) } \\
\hline & \multicolumn{4}{|c|}{ Higher (many losses, but some high gains) } \\
\hline & & & & $\begin{array}{l}\text { Highest (very high } \\
\text { qualitative gains) }\end{array}$ \\
\hline
\end{tabular}

Source: Authors' elaboration

\subsection{The Mainstream Criticisms of SIBs Reconsidered}

Justification for public investments inevitably affects the tools that are used to evaluate and assess such investments. If we move away from a market-fixing justification toward a marketshaping/creating role, it is essential to reconsider how this different framework affects the evaluation of public investments and, therefore, related criticisms. 


\section{a. $\quad$ Financial Repression and Crowding Out}

Crowding out critics (see section 4.2) often assume that the state should not invest in profitmaking areas. Indeed, if the state does earn a profit this becomes a de facto indicator of "crowding out" - that is, hurting the private sector by affecting its ability to make its deserved profits (Mussler, 2013) or substituting for investments that would have been done anyway by profit-seeking firms (Cohen and Noll, 1991). Yet, once we admit that the state has not only fixed markets but also actively shaped and created them, such logic falls apart. Most bets that the state makes in the market creation process fail, as is also true for private venture capital. While private VC is described as a lead risk taker and investor, the public sector is not and, hence, unlike $\mathrm{VC}$, is not allowed to reclaim some of the returns from the upside in order to cover the inevitable downside (Mazzucato, 2013a; Lazonick and Mazzucato, 2013). This different view of the market process thus produces a different view of who has the "right" to make profits and why.

Furthermore, the crowding out hypothesis cannot apply to economies that are not close to full employment of resources or that have not seized all available productive opportunities (as when SIBs perform the countercyclical role). In the capital development role, SIBs crowd in investments (Aschauer, 1989) by playing a lead role in the economic development or industrialization strategy in order to create network synergies. In the new venture support role, SIBs dynamize in the economy by identifying and supporting young, high-tech firms. And in the challenge-led role, SIBs help envision the future and direct economic efforts to superior techno-economic paradigms.

\section{b. Misallocation of Resources Due to Political Biases}

If SIBs are essential to the process of economic development, then it is also essential to understand the appropriate structure for such development. Performing the developmental role requires SIBs to make choices, but not necessarily through a centralized system of decision making, insulated from private initiative. In fact, the experiences with developmental network states, on the one hand, and with soviet-style planned economies on the other, both show that success seems dependent on a system in which the state makes choices within a capitalist framework and in coordination with private agents. However, MFT is at odds with this alternative evidence-based conceptualization because it calls for the state to intervene as little as possible in the economy, and in a way that minimizes the risk of misallocation of resources due 
to political biases. This results in a structure that insulates SIBs from the private sector (to avoid issues such as agency capture), which, in turn, would result in a diminishing role for SIBs over time, through delegating or outsourcing its roles to private initiative. However, outsourcing often rids public institutions of the knowledge capacities and capabilities (around IT, for example) that are necessary for managing change (Kakabadse and Kakabadse, 2002). Without such talent and expertise, it is nearly impossible for SIBs to fulfill its roles of coordination and provision of direction to private actors, of discovering the cost structure of the economy to promote investments that foster economic development, and of identifying gazelles. In order to promote true economic development (and not just facilitate growth), SIBs must organize themselves so that they have the intelligence (that is, policy capacity) to formulate and execute bold policies, and the ability to experiment and explore the underlying landscape. Therefore, instead of insulating the state from the private initiative to avoid misallocation of resources, SIBs should be structured in a way that maximizes their "absorptive capacity" (Cohen and Levinthal, 1990) so that they can learn with and from private actors in a process of investment, discovery and experimentation. This is not in opposition to market forces, but complementary to them - the state (and SIBs) is making choices that coordinate private initiative so as to promote the capital development of the economy. Furthermore, even in the case of "pork-barrel" or "logrolling" projects, one could argue that investments do result in the build-up of regional competencies and firm-level capabilities that would otherwise not happen, and that lead in the long run to increased private $R \& D$ investments or higher marginal innovation yields by the regions or firms (Etzkowitz and Leydesdorff, 2000; David et al.,2000) - this seems to be the case, for instance, of investments in the Silicon Valley, which some accused of being engaged in pork-barrel politics (e.g., Rodgers, 1998).

\section{c. Incapacity to Pick Winners}

Market failure theory says little about cases in which the state is the lead investor and risk taker in capitalist economies. Having a vision of which way to drive an economy requires direct and indirect investment in particular areas - not just creating the conditions for change. This also requires crucial choices to be made, the fruits of which will create some winners, but also many losers. Therefore, focusing on failed cases of picking winners is misleading. The issue of picking winners involves SIBs adopting a portfolio approach for their investments (Rodrik, 2013). In such an approach, (a) success from a few projects can cover the losses from many 
projects and (b) the state learns from its losing investments (Mazzucato, 2013a). What matters in this approach is not so much the matching between failures and fixes, but an institutional structure that ensures winning policies provide enough "rewards" to cover for the losses, and that losses are used as learning cases to improve and renew future policies. In fact, new metrics and indicators are needed for evaluating SIBs' (and other public agencies') activities against stated goals (for instance, if the goal is to maintain employment, it may be warranted to bail out problematic companies). These should take into account also non-monetary and non-market outcomes, particularly in the case of mission-oriented (challenge-led) and transformative investments. One of the few comprehensive analyses of the results of a portfolio of governmental investments - investments in energy efficiency and fossil fuel projects by the US Department of Energy (DoE) — has shown that most projects resulted in negative returns on investment, with just a few resulting in positive (qualitative and quantitative) net benefits: the positive net results from the handful of projects were, however, enough to cover the costs of the whole portfolio (National Research Council, 2001).

\section{d. Inefficient Governmental Structures}

One key limitation of market failure theory is its inability to justify or explain the active role that the state has played in shaping and creating markets - not just fixing them when they failand promoting "great transformations." In the most economically successful and innovative countries, public policies go beyond fixing market failures. The state has been integral in promoting the industrialization of all currently developed countries, investing not only in basic research and infrastructure, but also picking and nurturing technologies, firms, and sectors (Reinert, 1999; Chang, 2002). In sum, active public policies have given direction to economic development and promoted great socio-economic transformations. Understanding the role of the state in coordinating and giving a direction to private initiative requires a broader conceptualization than that which is enabled by market failure theory, which results in static considerations and a limited focus on efficiency. However, when economic development and the transformation of the socio-techno-economic landscape is seen (1) as a non-probabilistic risk-taking process surmounted by uncertainty about technical and economic outcomes (Mazzucato, 2013a); (2) as a process of experimentation and discovery (Hirschman, 1967;

Rodrik, 2004); and (3) as a continuous process of learning that leads to some successes and failures measured beyond static monetary analysis of the costs and benefits attached to 
quantifiable outcomes, then the strict focus on the economic efficiency of governmental structures is misleading. Instead, a more appropriate focus for organizing SIBs (and other public agencies) should be on which skills/resources, capabilities, and structures can help increase the chances that an SIB will be effective both in learning and in establishing symbiotic partnerships with the private sector - and ultimately in implementing mission-oriented and transformative policies.

\section{CONCLUSION}

The importance of state investment banks in the economy, particularly for transformative goals, is increasingly evident. ${ }^{27}$ In particular, SIBs represent an important alternative to "old" missionoriented funding mechanisms. In a time in which many countries are trying to not only stimulate growth but to address key societal challenges, SIBs seem well positioned to effectively promote the much needed capital development of the economy in a smart, inclusive and sustainable direction. In this sense, analyzing, theorizing and constructively criticizing what is being done is a new agenda for economists, and we believe our novel framework represents a first step in this direction. In this paper, we developed the pillars of an alternative framework of SIBs. We propose three areas for future research that would help advance the framework and that represent a new research agenda for evolution, innovation and development:

- Development of indicators that help evaluate each of the four roles of state investment banks. This is necessary, because standard economic indicators that are used in market failure cost-benefit analyses fail to capture precisely the aspects that make the market failure perspective limited;

- Cross-comparison of different state investment banks and their models of operation. This could help to establish "best practices" that may increase the efficiency and effectiveness of SIBs; and

\footnotetext{
${ }^{27}$ This is not to say that private banks do not have a place to play in market economies - the opposite is true. But for private finance to achieve a productive, non-speculative role, appropriate regulations (including segmentation of activities) need to be in place, such as happened during the post-World War II 'golden age'. Indeed, public banking and regulated private finance are the two sides of Minsky's policy recommendation for a well-functioning financial system.
} 
- In-depth case studies of a single SIB or a single SIB program, particularly those that are most successful (generate positive returns) and mission oriented, respectively. This, too, would help to establish best-practices.

State investment banks are not uniform in their size, scope, and structure; they differ along many dimensions such as funding source and cost; ownership type; direct or indirect funding (via private agents); activities, program, portfolio of investments, and financing tools; regulatory environment and specific bylaws; priorities; and performance, among other aspects. ${ }^{28}$ Thus, future research could seek to address more specific questions, such as:

- Is the investment in low-risk, big players always warranted? When should SIBs pull out?;

- Does it matter and what are the implications to be funded by the treasury/budget, central bank, or the market?;

- What are the implications of directly providing finance and of operating through private agents? What are the upsides and downsides?;

- How can the uncertainty of technological projects be appraised? How can portfolios of investments be structured? When should failed cases be discarded, and what should be done with them?

- Related to the previous question, what is the economically and socially acceptable number of failures that SIBs might afford to bear? ${ }^{29}$ Should SIBs engage in "martingale"-like strategy, whereby they increase their investments (and potential payoff) in order to cover for past failures?

We believe this represents a fruitful research agenda that could improve our understanding of the degree to which the activities of SIBs are opening up new technological landscapes and economic opportunities - making things happen that otherwise would not - and shaping and creating markets, and not only fixing them.

\footnotetext{
${ }^{28}$ Luna-Martinez and Vicente (2012) carried out a survey of 90 SIBs and offer a snapshot of the SIB population.

${ }^{29}$ We thank one of the anonymous referees for raising this important question.
} 


\section{References}

Abramovitz, M. 1986. "Catching Up, Forging Ahead, and Falling Behind," Journal of Economic History, 46, 385-406.

Adams, G., Williams, C., 2010. Buying National Security: How America Plans and Pays for Its Global Role and Safety at Home, Taylor \& Francis.

Aghion, P., David, P.A., Foray, D., 2009. "Science, Technology and Innovation for Economic Growth: Linking Policy Research and Practice in 'STIG Systems,"” Research Policy, 38, 681-693.

Amsden, A.H. 2001. The Rise of "the Rest": Challenges to the West from Late-Industrializing Economies, Oxford; New York, Oxford University Press.

Arrow, K. 1951. "An Extension of the Basic Theorems of Classical Welfare Economics," In: Neyman, J., ed. Second Berkeley Symposium on Mathematical Statistics and Probability. Berkeley: University of California Press.

Arrow, K.J. \& Lind, R.C. 1970. "Uncertainty and the Evaluation of Public Investment Decisions," The American Economic Review, 364-378.

Aschauer, D.A., 1989. "Does Public Capital Crowd out Private Capital?" Journal of Monetary Economics, 24, 171-188.

Bastos, V. 2012. “2000-2010: Uma Década de Apoio Federal à Inovação no Brasil,” Revista do BNDES, 19, 127-176.

Bleda, M., Del Río, P., 2013. "The Market Failure and the Systemic Failure Rationales in Technological Innovation Systems," Research Policy, 42, 1039-1052.

Block, F.L. \& Keller, M.R. 2011. State of Innovation: The U.S. Government's Role in Technology Development, Boulder, CO, Paradigm Publishers.

Bloom, N. \& Van Reenen, J. 2007. "Measuring and Explaining Management Practices across Firms and Countries," The Quarterly Journal of Economics, 122, 1351-1408.

BNDES 2012. Apoio à Inovação, Rio de Janeiro, BNDES.

Branco, C.E.C. 1994. "Apoio às Pequenas e Médias Empresas de Base Tecnológica: A Experiência do Contec," Revista do BNDES, 1, 129-142.

Brazilian Ministry of Finance. 2012. "Special Session: Green Economy," Brazilian Economic Outlook, 15.

Buchanan, J.M. 2003. "Public Choice: The Origins and Development of a Research Program," Champions of Freedom, 31, 13-32. 
Chang, H.J. 2002. Kicking Away the Ladder: Development Strategy in Historical Perspective, Anthem Press.

Climate Policy Initiative 2013. "The Global Landscape of Climate Finance 2013," In: Initiative, C.P. (ed.) CPI Report. Available from: http://climatepolicyinitiative.org/wpcontent/uploads/2013/10/The-Global-Landscape-of-Climate-Finance-2013.pdf [Accessed 3/9/2013].

Coase, R.H. 1960. "The Problem of Social Cost," Journal of Law \& Economics, 3, 1-44.

Cohen, L.R. \& Noll, R.G. 1991. The Technology Pork Barrel. Washington, D.C.: Brookings Institution.

Cohen, W.M. \& Levinthal, D.A. 1990. "Absorptive Capacity: A New Perspective on Learning and Innovation," Administrative Science Quarterly, 35.

Costa, F.N. 2011. “Geração De Funding,” [Online]. Available: http://fernandonogueiracosta.wordpress.com/2011/12/01/geracao-de-funding/ [Accessed 3/5/2013].

David, P.A., Hall, B.H. \& Toole, A.A. 2000. "Is Public R\&D a Complement or Substitute for Private R\&D? A Review of the Econometric Evidence," Research Policy, 29, 497-529.

De Aghion, B.A. 1999. “Development Banking," Journal of Development Economics, 58, 83100.

Debreu, G. 1959. Theory of Value: An Axiomatic Analysis of Economic Equilibrium, New York, Wiley.

Dodgson, M., Hughes, A., Foster, J., Metcalfe, S., 2011. "Systems Thinking, Market Failure, and the Development of Innovation Policy: The Case of Australia," Research Policy, 40, 1145-1156.

Dosi, G. 1982. "Technological Paradigms and Technological Trajectories: A Suggested Interpretation of the Determinants and Directions of Technical Change," Research policy, 11, 147-162.

Dosi, G. \& Nelson, R.R. 1994. "An Introduction to Evolutionary Theories in Economics," Journal of Evolutionary Economics, 4, 153-172.

Etzkowitz, H. \& Leydesdorff, L. 2000. "The Dynamics of Innovation: From National Systems and 'Mode 2' to a Triple Helix of University-industry-government Relations," Research Policy, 19, 109-123.

Etzkowitz, H. \& Ranga, M. 2009. "A Trans-Keynesian Vision of Innovation for the Contemporary Economic Crisis: 'Picking Winners' Revisited," Science and Public Policy, 36, 799-808. 
Fergusson, D. 1948. "The Industrial Development Bank of Canada," Journal of Business of the University of Chicago, 214-229.

Financial Times. 2012. “A Bank Too Big to Be Beautiful,” Financial Times, 24/9/2012.

Foray, D., Mowery, D. \& Nelson, R.R. 2012. "Public R\&D and Social Challenges: What Lessons from Mission R\&D Programs?” Research Policy, 41, 1697-1702.

Freeman, C., 1996. “The Greening of Technology and Models of Innovation,” Technological Forecasting \& Social Change, 53, 27-39.

Friedman, B.M. 1979. "Crowding Out or Crowding In? The Economic Consequences of Financing Government Deficits," Brookings Papers on Economic Activity, 3, 593-654.

FS-UNEP/BNEF 2013. Global Trends in Renewable Energy Investment 2013, BNEF.

Geels, F.W. 2013. "The Impact of the Financial-Economic Crisis on Sustainability Transitions: Financial Investment, Governance and Public Discourse," Environmental Innovation and Societal Transitions, 6, 67-95.

George, G. \& Prabhu, G.N. 2003. "Developmental Financial Institutions as Technology Policy Instruments: Implications for Innovation and Entrepreneurship in Emerging Economies," Research Policy, 32, 89-108.

Ghosh, S. \& Nanda, R. 2010. "Venture Capital Investment in the Clean Energy Sector," Harvard Business School Working Papers, 11-20.

Giambiagi, F., Rieche, F. \& Amorim, M. 2009. “As Finanças do BNDES: Evolução Recente e Tendências," Revista do BNDES, 16, 3-40.

Grant, R. 1982. “Government Cannot Pick Winners,” Economic Affairs, October, 29-32.

Griffith-Jones, S. \& Tyson, J. 2012. "The European Investment Bank and its Role in Regional Development and Integration," In: Cintra, M.A.M. \& Gomes, K.D.R. (eds.) The Transformations of the International Financial System. Brasília: IPEA, 2013. "The European Investment Bank: Lessons for Developing Countries," WIDER Working Paper.

Gutierrez, E., Rudolph, H. P., Homa, T. \& Blanco Beneit, E. 2011. "Development Banks: Role and Mechanisms to Increase Their Efficiency," World Bank Policy Research Working Paper.

Haltiwanger, J., Jarmin, R.S. \& Miranda, J. 2013. "Who Creates Jobs? Small Versus Large Versus Young," Review of Economics and Statistics, 95, 347-361.

Hanson, J.A. 2004. "Public Sector Banks and their Transformation," 6th Annual Financial Markets and Development Conference: The Role of State-Owned Financial Institutions Policy and Practice. Washington, DC: Brookings Institution Press. 
Hemming, R., Kell, M. \& Mahfouz, S. 2002. "The Effectiveness of Fiscal Policy in Stimulating Economic Activity - a Review of the Literature," IMF Working Paper Series, $\mathrm{WP} / 02 / 208$.

Hirschman, A.O. 1958. The Strategy of Economic Development, New Haven, Yale University Press.

1967. Development Projects Observed. Washington, DC: Brookings Institution Press.

Hochstetler, K. \& Montero, A.P. 2013. “The Renewed Developmental State: The National Development Bank and the Brazil Model," The Journal of Development Studies, 49, 1484-1499.

Hur, S.K., Mallick, S. \& Park, D. 2010. "Fiscal Policy and Crowding out in Developing Asia," ADB Economics Working Paper Series, 222.

Kakabadse, A. \& Kakabadse, N. 2002. "Trends in Outsourcing: Contrasting USA and Europe," European Management Journal, 20, 189-198.

Keynes, J. M. 1926. The End of Laissez-Faire, London, Prometheus Books.

Keynes, J. M. 1980. “Activities 1940-46. Shaping the Post-War World: Employment and Commodities.," In: Moggridge, D. (ed.) Collected Works. London: MacMillan.

Keynes, J. M. 2006 [1936]. General Theory of Employment, Interest and Money, Atlantic.

KfW 2009. KfW Annual Report 2008, Frankfurt am Main, KfW Group.

KfW 2010. KfW Annual Report 2009, Frankfurt am Main, KfW Group.

KfW 2012. KfW Annual Report 2011, Frankfurt am Main, KfW Group.

Kregel, J. 2009. "The Global Crisis and the Implications for Developing Countries and the BRICs: Is the B Really Justified?” Levy Institute Public Policy Brief, 102.

Krueger, A.O. 1974. "The Political Economy of the Rent-Seeking Society," The American Economic Review, 64, 291-303.

Krueger, A.O. 1990. “Government Failures in Development," Journal of Economic Perspectives, 4, 9-23.

Lall, S., 2002. "Social Capital and Industrial Transformation," in: Fukuda-Parr, S., Lopes, C., Malik, K. (Eds.), Capacity for development: new solutions to old problems. UNDP, New York and London pp. 101-119.

La Porta, R., Lopez - de - Silanes, F. \& Shleifer, A. 2002. "Government Ownership of Banks," The Journal of Finance, 57, 265-301. 
Lazzarini, S. G., Musacchio, A., Bandeira-de-Mello, R. \& Marcon, R. 2015. "What do StateOwned Development Banks do? Evidence from BNDES, 2002-09," World Development, 66, 237-253.

Lazonick, W. \& Mazzucato, M. 2013. "The Risk-Reward Nexus in the Innovation-Inequality Relationship: Who Takes the Risks? Who Gets the Rewards?" Industrial and Corporate Change, 22, 1093-1128.

Leahy, J. 2013. "Brazil: The Creaking Champions," Financial Times, 21 April, online, [Accessed 3/9/2013].

Levy-Yeyati, E., Micco, A. \& Panizza, U. 2004. "Should the Government be in the Banking Business? The Role of State-Owned and Development Banks.," IDB Working Paper.

Lisboa, M. D. B. \& Latif, Z. A. 2013. "Democracy and Growth in Brazil," Insper Working Paper, 311/2013.

Luna-Martinez, D. \& Vicente, C.L. 2012. "Global Survey of Development Banks,” World Bank Policy Research Working Paper.

Mankiw, N.G., Romer, D., 1991. New Keynesian economics. MIT Press, Cambridge, Mass.

Martin, S., Scott, J.T., 2000. "The Nature of Innovation Market Failure and the Design of Public Support for Private Innovation," Research Policy, 29, 437-447.

Mattos, P.T.L. 2008. "Institutions for Industrial Development and Innovation: The State as a Risk Taker in Brazil," Law and the New Developmental State (LANDS) Project Report.

Mazzucato, M. 2013a. The Entrepreneurial State: Debunking the Public vs. Private Myth in Risk and Innovation, Anthem Press.

Mazzucato, M. 2013b. Financing Innovation: Creative Destruction Vs. Destructive Creation. Industrial and Corporate Change, 22, 851-867.

Mckinnon, R. 1973. Money and Capital in Economic Development, Washington, DC: Brookings Institution Press.

Micco, A. \& Panizza, U. 2004. "Bank Ownership and Lending Behavior," Inter-American Development Bank Working Paper, 520.

Minsky, H.P. 1992. "The Capital Development of the Economy and the Structure of Financial Institutions," Levy Institute Working Paper Series, 72. 1993. Community Development Banks: An Idea in Search of Substance. Hyman P. Minsky Archive, Paper 278.

Minsky, H.P. \& Whalen, C. 1996. "Economic Insecurity and the Institutional Prerequisites for Successful Capitalism," Levy Institute Working Paper Series, 165. 
Mowery, D. C. 2010. "Military R\&D and Innovation,” In: Hall, B. H. \& Rosenberg, N. (eds.) Handbook of the Economics of Innovation. 1219-1256.

Mowery, D.C. 2012. “Defense-related R\&D as a Model for 'Grand Challenges' Technology Policies," Research Policy, 41(10), pp. 1703-1715.

Mowery, D. C., Nelson, R. R. \& Martin, B. R. 2010. “Technology Policy and Global Warming: Why New Policy Models Are Needed (or Why Putting New Wine in Old Bottles Won't Work)," Research Policy, 39, 1011-1023.

Mussler, H. 2013. “Germany’s Vampire Squid,” Financial World, February, 28-29.

National Research Council. 2001. Energy research at DOE: was it worth it? National Academy Press.

Nelson, R.R., Langlois, R.N., 1983. "Industrial Innovation Policy: Lessons from American History," Science, 219, 814-818.

Nelson, R.R. \& Winter, S.G. 1982. An Evolutionary Theory of Economic Change, Cambridge, MA: Belknap Press.

Nightingale, P. \& Coad, A. 2014. "Muppets and Gazelles: Political and Methodological Biases in Entrepreneurship Research," Industrial and Corporate Change, 23, 113-143.

Nurkse, R. 1966. Problems of Capital Formation in Underdeveloped Countries, New York, Oxford University Press.

O’Sullivan, M. 2004. "Finance and Innovation," In: Fagerberg, J., Mowery, D.C. \& Nelson, R. R. (eds.) The Oxford Handbook of Innovation. New York: Oxford University Press, 240-265.

Papadimitriou, D.B. \& Wray, L.R. 1998. "The Economic Contributions of Hyman Minsky: Varieties of Capitalism and Institutional Reform," Review of Political Economy, 10, 199-225.

Perez, C. 2002. Technological Revolutions and Financial Capital: The Dynamics of Bubbles and Golden Ages, Cheltenham, UK; Northampton, MA: Edgar Elgar.

Pinheiro, A.C., 2000. “A experiência brasileira de privatização: o que vem a seguir?,” Second Annual Global Development Network Conference, Tokyo, December 10-13.

Pinto, L.F.G. 1997. "Capital de Risco: Uma Alternativa de Financiamento às Pequenas e Médias Empresas de Base Tecnológica-O Caso do Contec," Revista do BNDES, 7.

Polanyi, K. 2001 [1944]. The Great Transformation: The Political and Economic Origins of Our Time, Boston, MA, Beacon Press.

Portugal, M. 2013. "O Brasil no Longo Prazo: Financiamento da Infraestrutura e das Empresas," Fórum Carta Capital, São Paulo, 7 May. 
Prebisch, R. 1950. "The Economic Development of Latin America and its Principal Problems," Economic Bulletin for Latin America, 7, pp. 1-12.

Ramundo, J. 2013. "Challenges of Financing Innovation," Presentation for the Minds' Conference on Financial Institutions for Innovation and Development, June 28.

Reinert, E.S. 1999. "The Role of the State in Economic Growth," Journal of Economic Studies, $26,268-326$.

Rodgers, T. 1998. "Silicon Valley vs. Corporate Welfare," Cato Institute Briefing Paper, 37.

Rodrik, D. 2004. "Industrial Policy for the Twenty-First Century," John F. Kennedy School of Government Working Paper Series, rwp04-047.

Rodrik, D. 2013. “Green Industrial Policy,” Princeton University Working Paper.

Sanderson, H. \& Forsythe, M. 2013. China's Superbank: Debt, Oil and Influence - How China Development Bank Is Rewriting the Rules of Finance. Singapore: John Wiley \& Sons.

Schapiro, M. G. 2012. "Rediscovering the Developmental Path? Development Bank, Law, and Innovation Financing in the Brazilian Economy," SSRN Working Paper.

Schröder, M., Ekins, P., Power, A., Zulauf, M. \& Lowe, R. 2011. The KfW Experience in the Reduction of Energy Use in and $\mathrm{Co}_{2}$ Emissions from Buildings: Operation, Impacts and Lessons for the UK. London: UCL Energy Institute, University College London and LSE Housing and Communities, London School of Economics.

Schumpeter, J.A. 1934 [1912]. The Theory of Economic Development: An Inquiry into Profits, Capital, Credit, Interest, and the Business Cycle, Cambridge, MA: Harvard University Press.

1939. Business Cycles; a Theoretical, Historical, and Statistical Analysis of the Capitalist Process. New York, London: McGraw-Hill.

2002 [1912]. "Seventh Chapter of the Theory of Economic Development," Industry and Innovation, 9, 93-145.

Singer, H.W. 1950. "Comments to the Terms of Trade and Economic Development," Review of Economics and Statistics, 40, 84-89.

Soete, L., Arundel, A., 1993. An Integrated Approach to European Innovation and Technology Diffusion Policy: A Maastricht Memorandum. Commission of the European Communities, SPRINT Programme, Luxembourg.

Stern, N. H. 2006. The Economics of Climate Change (Stern Review). England: HM Treasury.

Stiglitz, J. 1974." Growth with Exhaustible Natural Resources: The Competitive Economy," Review of Economic Studies, 41, 139-152. 
Stiglitz, J. 1991. "The Invisible Hand and Modern Welfare Economics," NBER Working Paper, 3641.

Stiglitz, J. \& Weiss, A. 1981. "Credit Rationing in Markets with Imperfect Information," American Economic Review, 3, 393-410.

Tassey, G. 2012. "Beyond the Business Cycle: The Need for a Technology-Based Growth Strategy," Science and Public Policy, 40, 293- 315.

Tcherneva, P.R. 2008. "Keynes's Approach to Full Employment: Aggregate or Targeted Demand?" The Levy Economics Institute Working Paper Collection, 542.

Tchouvakhina, M. 2013. "Promotion of Innovations: No Money, No Ideas?" UNECE International Conference 'Entrepreneurship and Innovation', Dubrovnik, 23-24 May.

The Economist 2010. "Picking Winners, Saving Losers: The Global Revival of Industrial Policy," The Economist, 5 Aug, online.

Torres Filho, E.T. \& Costa, F.N.D. 2012. "BNDES e o Financiamento do Desenvolvimento," Economia e Sociedade, 21, 975-1009.

Tullock, G., Seldon, A., \& Brady, G.L., 2002. Government Failure: A Primer in Public Choice, Washington, DC: Cato Institute.

Wade, R. 1990. Governing the Market: Economic Theory and the Role of Government in East Asian Industrialization, Princeton, NJ: Princeton University Press.

Weber, K.M., Rohracher, H., 2012. "Legitimizing Research, Technology and Innovation Policies for Transformative Change: Combining Insights from Innovation Systems and Multi-level Perspective in a Comprehensive 'Failures' Framework," Research Policy, 41, 1037-1047.

Wheatley, J. 2013. "Brazil's BNDES: Crowding out, Not Crowding In," Financial Times, 24 Jan. Available: http://blogs.ft.com/beyond-brics/2013/01/24/brazils-bndes-crowding-outnot-crowding-in/ [Accessed Oct 29 2014].

Wilson, J., Bryant, C., 2008. "Lehman Payout Sparks KfW Rethink," Financial Times, 19 Sep, Available: http://www.ft.com/cms/s/0/221895cc-868a-11dd-959e-0000779fd18c.html [Accessed Oct 29 2014].

World Bank. 2013. History [Online]. Available: http://go.worldbank.org/65Y36GNQB0 [Accessed 2/2/2013.

Wray, L. R. 2012. “The Great Crash of 2007 Viewed through the Perspective of Veblen's Theory of the Business Enterprise, Keynes's Monetary Theory of Production and Minsky's Financial Instability Hypothesis," In: Reinert, E.S. \& Viano, F.L. (eds.) Thorstein Veblen: Economics for an Age of Crises. London: Anthem Press, 303-316. 
Wright, B.D. 2012. "Grand Missions of Agricultural Innovation,” Research Policy, 41, 17161728. 